Keleş, İ. H. \& Dede, H. (2020). REACT stratejisiyle "saf maddeler, karışımlar ve karışımların ayrılması" konularının öğretimi. Bolu Abant İzzet Baysal Üniversitesi Eğitim Fakültesi Dergisi, 20(4), 1657-1675. https://dx.doi.org/10.17240/aibuefd.2020.20.58249-618735

Makalenin Türü / Article Type Geliş Tarihi / Date Received Kabul Tarihi / Date Accepted Yayın Tarihi / Date Published
: Araștırma Makalesi / Researh Article

: 11.09 .2019

: 31.08 .2020

: 15.12 .2020

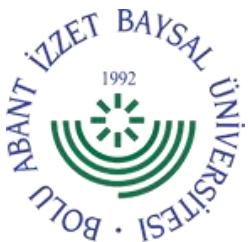

\title{
REACT STRATEJISIYYLE “SAF MADDELER, KARIŞIMLAR VE KARIŞIMLARIN AYRILMASI” KONULARININ ÖĞRETIMI“*
}

\author{
İbrahim Halil KELEŞ ${ }^{1}$, Hülya DEDE $^{2}$
}

ÖZ

Bu çalışmanın amacı, 7. sınıf fen bilimleri dersi "saf maddeler, karışımlar ve karışımların ayrılması" konularının REACT stratejisiyle öğretiminin öğrencilerin akademik başarılarına, fen öğrenmeye karşı motivasyonlarına, fen öğrenimine yönelik özyeterliklerine, fene yönelik sorgulayıcı öğrenme becerileri algıları ve bunların kalıcılığına etkisini incelemektir. Çalışma grubunu 7. sınıfta öğrenim gören 18 öğrenci oluşmaktadır. Araçsal durum çalışması yönteminin kullanıldığı çalışma 14 ders saati sürmüştür. Çalışmada nicel veriler Fen Öğrenmeye Yönelik Motivasyon Ölçeği [FÖYMÖ], Fen ve Teknoloji Dersi Özyeterlik Ölçeği [FTÖÖ], Fene Yönelik Sorgulayıcı Öğrenme Becerileri Algısı Ölçeği [FYSÖBAÖ] ve araştırmacı tarafından geliştirilen Madde Konusu Yaşam Temelli Başarı Testi [MK-YTBT] ile toplanırken, nitel veriler yarı yapılandırılmış öğrenci görüş formuyla toplanmıştır. Tüm nicel veri toplama araçları, uygulamadan önce ön test, uygulamadan sonra son test ve uygulamadan sekiz hafta sonra ise kalıcılık testi olarak uygulanmıștır. Çalışmada elde edilen nicel verilerden normal dağılım gösterenler bağımlı gruplar t-testi, normal dağılım göstermeyenler Wilcoxon İşaretli Sıralar Testi ile ve elde edilen nitel veriler ise betimsel analiz yöntemiyle analiz edilmiștir. Sonuçlar REACT stratejisinin öğrencilerin akademik başarılarını, fen öğrenimi özyeterliklerini ve fene yönelik sorgulayıcı öğrenme becerileri algılarını artırdığı ve bunların kalıcıllı̆ını sağladığ1 göstermiştir. Ayrıca çalışmada, REACT stratejisinin öğrencilerin fen öğrenmeye karşı motivasyonlarını artırmadığı fakat öğrencilerin fen öğrenmeye karşı motivasyonlarının kalıcılığını sağladığı sonucuna da ulaşılmıştır.

Anahtar Kelimeler: Akademik başarı, motivasyon, REACT stratejisi, sorgulayıcı öğrenme becerileri algısı, özyeterlik

\section{TEACHING "PURE SUBSTANCES, MIXTURES AND SEPARATION OF MIXTURES" TOPICS WITH REACT STRATEGY}

\begin{abstract}
The purpose of this study is to examine the 7th grade science lesson subjects pure substances, mixtures and the separation of mixtures to see the academic success of students, motivation of science learning, the perception of science learning by questioning and the permanence of these studies with REACT strategy. The working group of study was composed total of 18 students, who are 7th grade. The research, in which the instrumental case study research method was used, lasted about 14 lesson time. While the quantitative data collected through Matter Subject Context Based Success Test [MSCB-ST] developed by researchers, Questionnaire for Motivation toward Science Learning [QMSL], Self-Efficacy Scale towards Science and Technology [SESST] and Measurement of Inquiry Learning Skills Perception Devise [MILSPD], the qualitative data collected through Semi-Structured Student Opinion Form. All quantitative data collection tools were applied as pre-test before application, post-test after application and retention test eight weeks after the application. In the study, the quantitative data matching the normal distribution were analyzed by the dependent group's t-test, the data that did not fit the normal distribution by Wilcoxon Signed Rank Test and the qualitative data were analyzed by descriptive analysis method. The results demonstrated that REACT strategy increases students' academic achievement, self-efficacy in science education, and perceptive learning skills for science and permanence of all them. However, it was seen that the REACT strategy provides the persistence of the motivation while not having a statistically significant effect on the motivation of students towards science learning.
\end{abstract}

Keywords: Academic success, science, motivation, REACT strategy, inquiry learning skills perception, self-efficacy

\footnotetext{
" Bu makale birinci yazarın ikinci yazar danışmanlığında Kilis 7 Aralık Üniversitesi Fen Bilimleri Enstitüsünde gerçekleştirdiği yüksek lisans tez çalışmasından üretilmişstir.

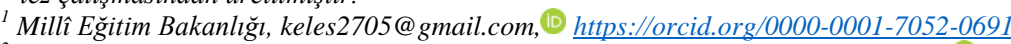

${ }^{2}$ Kilis 7 Aralı Üniversitesi, Muallim Rlfat Eğitim Fakültesi, hulyakutu@kilis.edu.tr, (1) https://orcid.org/0000-0002-3460-3307
} 


\section{GíRiş}

Bilimin ve teknolojinin hızla gelişip ilerlemesi, öğrenme-öğretme süreçlerinin de gelişimini gerekli kılmıştır. Hem hızla gelișen bilim ve teknolojiye ayak uydurabilecek hem de bilim ve teknolojinin gelişimine katkı sağlayacak nesillerin yetiştirilmesi gerekliliği, artık daha etkili öğrenme ve öğretme yaklaşım ve kuramlarının kullanımını bir zorunluluk hâline getirmiştir (Karaman \& Karaman, 2016). Öğrenme sürecinin doğasını açıklayan ve öğretim sürecinin nasıl gerçekleştirilmesi gerektiğini bildiren pek çok öğrenme kuramı ortaya atılmıștır.

Dünya genelinde 1980'li yıllardan bu yana yapılandırmacı öğrenme yaklaşımı diğer yaklaşımlar arasından sıyrılarak, pek çok eğitim reformunun çıkış noktası olmayı başarmıştır (Bächtold, 2013; Fosnot, 1996; Wang, 2013; Wilson, 1996). Yapılandırmacılık, başta öğrencilerin bilgiyi nasıl öğrendiğini açıklamaya çalışan bir kuram iken, daha sonra süreç içerisinde öğrencilerin bilgiyi nasıl yapılandırdığını açıklayan bir yaklaşıma dönüşmüştür. Yapılandırmacı yaklaşıma göre öğrenme ezberleme yoluyla değil, var olan bilgiyi yeniden yorumlama yoluyla gerçekleşir. Öğrenciler mevcut bilgileri ile yeni öğreneceği bilgiyi uyumlu hâle getirerek bilgiyi yapılandırır ve öğrendiği bilgileri günlük yaşamında karşılaştığı problemleri çözmede kullanırlar (Bodner, 1986; Perkins, 1999). Fen eğitimi alanında yapılandırmacı yaklaşım temelli eğitim öğretim faaliyetlerinin incelendiği çalışmalar, yaklaşımın öğrencilerde anlamlı ve kalıcı öğrenmeyi sağladığını göstermiştir (Akyol, 2011; Çetin \& Günay, 2007; Karaduman \& Gültekin, 2007; Keengwe \& Oncwari, 2011; Oguz, 2008). Ancak yapılan bazı çalışmalar yapılandırmacı yaklaşımının, öğrencilerin fen konularını günlük yaşamla ilişkilendirebilmeleri ve neden öğrenmeleri gerektiğini anlamalarını sağlamada yetersiz olduğunu göstermektedir (Gilbert, 2006; Karagölge \& Ceyhun, 2002; Özmen, 2003; Stolk vd., 2009; Yıldırım \& Konur, 2014).

Yapılandırmacı yaklaşımın öğrencilerde anlamlı ve kalıcı öğrenmeyi sağladığı fakat öğrencilerin fen konularının günlük hayatla ilişkilendirebilme sorununa çare olamadığı görülmektedir. $\mathrm{Bu}$ sorunun üstesinden gelmek amacıyla ortaya atılan yaşam temelli öğrenme yaklaşımı ile öğrencilere fen kavramları günlük hayattan olaylarla gösterilir ve böylelikle öğrencilerin fene karşı motivasyonları yükseltilir, öğrencilerin fen bilimleri ile günlük yaşamlarında karşılaştıkları olaylar arasındaki ilişkinin farkına varmaları sağlanır (Sözbilir vd., 2007). Temeli yapılandırmacılığa uzanan yaşam temelli öğrenme yaklaşımını 1980'li yılların başında İngiltere'de York Üniversitesinde kendilerini Salters grubu olarak adlandırdıkları bir grup kimya eğitimcisi tarafindan ortaya atılmıştır. Yaşam temelli öğretim yaklaşımı bir eğitim öğretim yaklaşımından daha fazla bir öğretim programı geliştirme yaklaşımı olarak geliştirilmiştir (Bennett \& Lubben, 2006; Kutu, 2011). Gilbert'a göre (2006), dünya genelinde 1980'li yıllardan sonra geliştirilen fen/kimya öğretim programlarının aşırı bilgi yüklü olması, konuların transferinde eksiklik olması, öğrencilerin öğrendiklerine anlam verememesi, öğrencilerin konuyu öğrenme ihtiyacı hissetmemesi gibi fen/kimya eğitiminin birbiriyle ilişkili birtakım sorunlarıyla karşılaşmıştır. Bu sorunlar, çoğu öğrencinin fen öğretim programlarını soyut, zor ve günlük hayatla ilişkisiz olarak görmesine neden olmuştur (De Vos vd., 2002; Osborne \& Collins, 2001). Dolayısıyla öğrencilerin fene karşı ilgilerinin azaldığ1 ve yükseköğretimde fen ile ilgili bölümlere tercihlerde düşüş olduğu görülmüştür (Gilbert vd., 2002). $\mathrm{Bu}$ sorunlara çözüm olabilmek amacıyla birçok ülkede, fen eğitimi alanında reform hareketleri başlatılarak, öğretim programları yeniden düzenlenmiştir. Bu reform hareketlerinden biri olan yaşam temelli öğrenme yönteminde, öğretimin başında öğrencilere bilimsel kavramlar, "öğrenme ihtiyacı” temelinde, yaşamlarındaki olaylarla bağlantılı bir şeklide oluşturulan bağlamlar içerisinde verilmektedir (Bennett vd., 2006; Ramsden, 1997). Başta İngiltere olmak üzere, Amerika, Almanya, Hollanda ve İsrail öğretim programlarını iyileştirme çalışmalarında yaşam temelli öğretim modeli yer almıştır (Bennett \& Lubben, 2006; Pilot \& Bulte, 2006). Ülkemizde de 2007 yılında yayımlanan fizik öğretim programında yaşam temelli öğretim yaklaşımı esas alınmıştır (MEB, 2007).

Yaşam temelli öğrenme yönteminde bilimsel kavramlar öğrencilere öğrenme ihtiyacı temelinde (Bulte vd., 2006), günlük yaşamdaki olaylarla ilgili bağlamlar oluşturularak verilmektedir (Barker \& Millar, 1999). De Jong'a göre (2008) bağlam, öğrencilerin fen konu ve kavramlarına anlam verebilmelerine yardımcı olan, yaşanmış ya da yaşanması olası durum olarak tanımlanmaktadır. Derse konu ile ilgili bir bağlam ile başlanarak, ögrrencilerin derse karşı motivasyonun artması ve işlenen fen konusunun günlük yaşamdaki yeri ve öneminin daha iyi anlaşılması hedeflenmektedir. Bu nedenle yaşam temelli öğretim yaklaşımında bağlamlar belirlenirken bunların öğrencilerin aşina oldukları durumlardan seçilmesine, yaş düzeylerine uygun olmasına, öğrencilerin dikkatini işlenen konudan uzaklaştırmamasına, kafa karıştırıcı olamamasına ve öğrencilerin anlayabileceği zorlukta olmasına dikkat edilmektedir (De Jong, 2008). Yaşam temelli öğrenme modelinin amac1, öğrencilerin fen bilimleri dersine karşı ilgilerini arttırmak, günlük yaşam ile fen bilimleri arasındaki ilişkiyi fark etmelerini sağlamak, öğrencilerde kapsamlı fen anlayışı oluşturmak ve fen okuryazarı bireyler yetiştirmektir (Karamustafaoğlu vd., 2018).

Bir öğretim tasarımı olarak yaşam temelli öğretim yaklaşımı, öğretim ortamında ChiK'in önerdiği dört aşamalı modeli, 5E modeli, REACT stratejisi, ARCS motivasyon modeli gibi birçok öğretim modeli ile desteklendiği 
görülmektedir (Kutu, 2011). Bu modeller arasından REACT stratejisi, fen eğitiminde kullanımı giderek artan bir eğilim göstermektedir (Coştu, 2009; Crawford, 2001; Crawford \& Witte, 1999; Değermenci, 2009; Demircioğlu vd., 2012; Gül, 2016; Gül vd., 2017; House, 1996; Ingram, 2003; Navarra, 2006; Tanner \& Chism, 1996; Ültay, 2012; Ültay \& Çalık, 2011; Ültay vd., 2015).

REACT stratejisi, ilk olarak CORD (1999), Souders (1999) ve Crawford'un (2001) yapmış oldukları çalışmalarda yer almış ve tanıtılmıştır. CORD’a göre (1999) REACT stratejisi, öğretmenlerin oluşturdukları örnek materyaller ve görüşleri doğrultusunda ortaya çıkmıştır. REACT stratejisi öğrenci merkezli eğitim anlayışına dayanır. REACT stratejisinde öğrenciler bilimsel bilgileri ezberlemek yerine, bilimsel bilgilerin günlük hayatlarıyla ilişkisini öğrenerek ve değişik olaylarda bilimsel bilgileri kullanarak, derste öğrendiği bilgilerin bir işe yaramayacağı algısından kurtulmaktadır. Öğretmenler REACT stratejisiyle, sınıf ortamındaki tüm öğrencilerin aktif katılımlarını sağlayacak bir öğrenme ortamı oluşturmaktadır (Navarra, 2006). REACT stratejisi beş basamaktan oluşmaktadır (Crawford, 2001; Crawford \& Witte, 1999). Ültay ve Çalık (2011) REACT stratejisinin basamaklarını ve özelliklerini şöyle açıklamaktadır:

1- İlişkilendirme basamağı (Relating): Yeni öğretilecek konu ya da kavram öğrencilerin günlük yaşamdan bildikleri olaylarla ya da ön bilgilerle ilişkilendirildiği bağlamlar yoluyla verilir. Bağlamların gerçek ya da gerçeğe çok yakın olması gerekmektedir.

2- Tecrübe etme basamağı (Experiencing): Bu aşamada manipulatifler (öğrencilerin soyut kavramları modelleyerek somutlaştırabilecekleri basit nesneler), problem çözme aktiviteleri veya laboratuvar etkinlikleri kullanılır. Öğrenciler bu sayede tecrübelenir, öğrendiği bilgiyi yapılandırır ve soyut olayları somut bir şekilde modelleyerek öğrenir. Öğretmen bu basamakta öğrencilere rehberlik eder.

3- Uygulama basamağı (Applying): Öğrenciler yeni konu ya da kavramı kullanabilecekleri problem çözme aktiviteleri ya da proje çalışmalarını yaparak öğrenirler. Bu basamakta, yaşamlarındaki gerçekçi olaylarla, mantıklı ve ilgilerini çekebilecek durumlarla kavramların kullanıldığı bir ortam yaratılmalıdır. Öğrencilere görev olarak öğrencinin yaparak yaşayarak içinde bulunduğu aktiviteler, gerçekle uyumlu aktiviteler verilmelidir. Bu sayede öğrenciler konu ya da kavramları anlamaya adapte olurlar.

4- İşbirliği basamağı (Cooperating): Çoğu gerçeğe uygun problem çözme aktiviteleri karmaşı olduğu için öğrenciler bireysel çözmeye çalıştıklarında çoğu zaman olumsuz sonuçlanmaktadır. Öğrenciler akranlarıyla çalıştıklarında bireysel stres ve kaygı düzeyleri azaldığı için, küçük gruplar halinde işbirliği içerisinde problemi dışarıdan küçük bir yardımla kolaylıkla çözebilirler. Bu basamakta öğrenciler gruplar halinde problem çözmek, yaşamlarından verilen gerçekçi senaryolara çözüm üretmek veya araştırma yapmak için işbirliği içerisinde hareket ederler. Gruptaki her bir öğrencinin bir görevi olup, her öğrenci görevini en iyi şekilde yapmaya çalışır. Ayrıca, diğer öğrenci gruplarıyla fikir alışverişi yapıp çalışmalarına tekrar göz atabilirler.

5- Transfer etme basamağı (Transferring): Yeni bilgileri edinen öğrencilerden, bu bilgilerini daha önceden karşılaşmadıkları yeni durumlarda kullanmaları beklenmektedir. $\mathrm{Bu}$ yeni bilgileri yeni durumlara transfer etmelerini kolaylaştırmak amacıyla öğrencilere tartışma yaptırılabilir ya da proje ödevi verilebilir.

REACT stratejisi ile öğrencilerin, öğrendikleri fen bilgisi becerilerinin kendilerini, çevrelerini ve yaşamlarını değerlendirmede, günlük yaşamda karşılaştıkları problemleri ve sorunları çözmede çözüm bulabileceğine inanılmaktadır. Çünkü bu stratejiyi kullanan bir öğretmen, tüm öğrencilerineher türlü konuyu öğrenebileceği bir öğrenme ortamı sağlayacaktır (Navarra, 2006; Ültay \& Çalık, 2011). Demircioğlu vd.'ne göre (2012) REACT stratejisi, günlük hayattaki uygulamalara ve günlük hayattaki olaylara kaynak gösterilerek, öğrencilerin ön bilgileri ve hayat tecrübelerindeki bağlamlarla anlatarak öğrenmelerini sağlamaktadır.

Alanyazında REACT stratejisi ile fen (ortaokul fen, ortaöğretim fizik, kimya ve biyoloji) öğretimi üzerine yapılan çalışmalar, öğrencilerin başarıları (Aktaş, 2013; Ayvacı \& Bebek, 2018; Bilgin, 2015; Bilgin vd., 2017; Demircioğlu vd., 2019; Gül vd., 2017; Günter, 2018; Ingram, 2003; Karaş, 2019; Keskin \& Çam, 2018; Kumaş, 2015; Saka, 2011), öğrenmenin kalıcılığı (Gül, 2016; Karaş, 2019; Karslı \& Yiğit, 2017; Sevinç, 2015; Ültay, 2014), kavramsal anlamaları (Ayvacı \& Bebek, 2018; Ayvacı vd., 2016; Karslı-Beydere \& Aydın, 2019; Sevinç, 2015; Ültay, 2014), kavramsal değişimleri (Bilgi vd., 2017; Bilgin, 2015; Demircioğlu vd., 2012; Karslı \& Yiğit, 2017; Kumaş, 2015; Ültay vd., 2015; Yiğit, 2015), ilgileri (Ingram, 2003; Sevinç, 2015), fen okuryazarlıkları (Keskin \& Çam, 208) üzerinde ve öğrenme güçlüklerinin giderilmesinde (Kumaş, 2015) olumlu etkileri olduğunu göstermektedir. Ayrıca REACT stratejisinin öğrencilerde olumlu tutum (Demircioglu vd., 2019; Ingram, 2003), motivasyon (Demircioğlu vd., 2019; Gül vd., 2017; Ingram, 2003), ve sorgulayıc1 öğrenme becerisi (Demircioglu vd., 2019) geliştirdiği çalışmalar bulunmakla birlikte sorgulayıcı öğrenme becerisi (Gül, 2016; Gül vd., 2017), tutum ve motivasyon (Gül, 2016; Karaş \& Gül, 2019) üzerinde herhangi bir etkisinin bulunmadığı çalışmalar da mevcuttur. 


\subsection{Araştırmanın amacı}

Bu çalışmanın amacı "7. sınıf fen bilimleri dersi "saf maddeler, karışımlar ve karışımların ayrılması” konularının yaşam temelli öğrenme yöntemine dayalı REACT stratejisi ile öğretiminin öğrencilerin akademik başarılarına, fen öğrenmeye karşı motivasyonlarına, fen öğrenimi özyeterliklerine, fene yönelik sorgulayıcı öğrenme becerileri algıları ve bunların kalıcılığına etkisini” incelemektir. Bu amaç doğrultusunda aşağıda yer alanaraştırma sorularına cevap bulmaya çalışılmıştır. Bunlar;

1. REACT stratejisine dayalı öğretimin öğrencilerinin "saf maddeler, karışımlar ve karışımların ayrılması" konusuna ilişkin akademik başarılarına ve akademik başarılarının kalıcılığına etkisi nedir?

2. REACT stratejisine dayalı öğretimin öğrencilerinin fen öğrenmeye karşı motivasyonlarına ve fen öğrenmeye karşı motivasyonlarının kalıcılı̆̆ına etkisi nedir?

3. REACT stratejisine dayalı öğretimin öğrencilerinin fen öğrenimi özyeterliklerine ve fen öğrenimi özyeterliklerinin kalıcılığına etkisi nedir?

4. REACT stratejisine dayalı öğretimin öğrencilerin sorgulayıcı öğrenme becerisi algılarına ve sorgulayıcı öğrenme becerisi algılarının kalıcılığına etkisi nedir?

\subsection{Araştırmanın önemi}

Öğrencilerin fen okuryazarı olarak yetiştirilmesi yaşam temelli öğretim yönteminin amaçlarından biri olduğu gibi, ayrıca 2005, 2013 ve 2018 fen öğretim programlarının ortak amaçları arasındadır (Bakaç, 2019). Fen okuryazarı olabilmek için öğrencilerin; araştıran-sorgulayan, etkili kararlar verebilen, problem çözebilen, kendine güvenen, etkili iletişim kurabilen, işbirliğine açık, yaşam boyu öğrenen bireyler olmaları gerekmektedir (MEB, 2013). Bu nedenle öğrencilerin sorgulayıcı öğrenme becerilerinin ve fen öğrenmeye karşı özgüvenlerinin gelişmesinin önemli olduğu söylenebilir. Bu nedenle bu çalışmada özellikle yaşam temelli öğretim yönteminin öğretim ortamında yürütülmesinde kullanılan REACT stratejisinin, öncelikle öğrencilerin sorgulayıcı öğrenme becerileri ve fen öğrenimi özyeterliklerinin gelişimi olmak üzere, başarıları ve motivasyonları ile bunların kalıcılıkları üzerindeki etkisinin incelenmesi hedeflenmiştir. Özelikle REACT stratejisinin öğrencilerin matematik öğrenimi öz-yeterlikleri üzerinde olumlu etkisinin olduğu (Fadhilah, 2017) çalışmalar olmasına rağmen, fen öğrenimi özyeterlikleri üzerinde etkisini ortaya koyan herhangi bir çalışmaya rastlanmamış olması, mevcut çalışmanın özgün değerleri arasındadır. Bir diğer özgün değerini ise, REACT stratejisinin sadece başarı gibi bilişsel değişkenin kalıcılığı üzerindeki etkisinin değil, ayrıca motivasyon, özyeterlik ve sorgulayıcı öğrenme becerisi gibi duyuşsal değişkenlerin de kalıcılığı üzerindeki etkilerinin incelenmesidir.

Madde konusu, fen bilimlerinin en temel ve önemli konularından biridir (Demirci Güler, 2008; Erdem vd., 2004). İlkokuldan üniversiteye kadar tüm fen bilimleri programlarda yer almaktadır (Özarslan \& Bilgin, 2016). İlköğretim düzeyindeki öğrencilerin madde konusunda yer alan kavramları tam olarak anlamlı bir şekilde öğrenememesi durumunda, ilerleyen yıllarda kimyanın diğer konularında, daha ciddi anlama ve kavrama sorunlarıyla karşı karşıya kalabilmektedirler (Karaer, 2007). Dolayısıyla, bu çalışmada REACT stratejisiyle öğretimini yapmak üzere, madde konusunun kavramlarından olan, saf madde, karışım ve karışımların ayrılması konuları tercih edilmiştir. Çalışmanın, madde konusunun öğretiminde zengin öğrenme ortamlarının oluşturulmasına ve REACT stratejisinin kullanımının etkinliğinin belirlenmesinde yardımcı olarak bu konuda mevcut alan yazına önemli katkı sağlayacağı öngörülmektedir.

\section{YÖNTEM}

Araştırma yöntemi olarak araçsal (instrumental) durum çalışması yöntemi kullanılmıştır. Araçsal durum çalışmalarında özel bir olay, etkinlik veya durum incelenerek genel yargıya varılmakta ve olayın kendisinden daha çok etkileri incelenmektedir (Stake, 2003). Bu çalışmanın temel amacı REACT stratejisinin kendisini değil, REACT stratejisinin öğrencilerin akademik başarıları, fen dersine karşı motivasyonları, fen öğrenimi özyeterlikleri ve sorgulayıcı öğrenme becerisi algılarına etkisini incelemektir.

\section{1. Çalışma grubu}

Çalışma grubunu 2017-2018 eğitim-öğretim yılı güz döneminde, Kilis ilinde yer alan bir ortaokulun 7. sınıfında öğrenim gören 9 kız, 9 erkek olmak üzere toplam 18 öğrenci oluşturmaktadır. Çalışma grubu, amaçlı örnekleme yöntemlerinden kolay ulaşılabilir örnekleme yöntemiyle belirlenmiştir. Kolay ulaş1labilir örnekleme yönteminde araştırmacı yakın ve ulaşılması kolay bir durumu seçmekte ve böylece araştırmacı zaman kazanmış olmaktadır (Yıldırım \& Şimşek, 2016, s.123). 


\subsection{Veri toplama araçları}

$\mathrm{Bu}$ çalışmada hem nicel hem de nitel birden fazla sayıda veri toplama araçları birlikte kullanılarak çeşitleme yoluyla çalışmanın geçerliği ve güvenirliği arttırılmaya çalışılmıştır (McMillan \& Schumacher, 2016, s. 91). Aşağıda çalışmada kullanılan veri toplama araçları ayrıntılı bir şekilde yer almaktadır.

\subsubsection{Madde Konusu Yaşam Temelli Başarı Testi (MK-YTBT)}

Öğrencilerin "saf maddeler, karışımlar ve karışımların ayrılması” konularındaki akademik başarıları ve akademik başarılarının kalıcılığı ölçmek amacıyla araştırmacılar tarafından geliştirilmiş olan "Madde Konusu Yaşam Temelli Başarı Testi (MK-YTBT)"nden yararlanılmıştır. MK-YTBT için ilk olarak konulara ait fen bilimleri öğretim programında yer alan kazanımlar ve Bloom’un revize edilmiş taksonomisi dikkate alınarak belirtke tablosu hazırlanmıştır. Mümkün olduğunca her kazanıma ait, farklı bilişsel düzeylerde soru olmasına dikkat edilerek toplam 25 adet çoktan seçmeli sorudan oluşan testin ilk hâli oluşturulmuştur. Geliştirilen testin kapsam geçerliğini sağlamak ve bilimsel doğruluğunu incelemek amacıyla bir fen eğitimi uzmanı ve iki fen bilimleri öğretmeninin görüşleri alınmıştır. Uzman ve öğretmenlerin dönütleri doğrultusunda gerekli düzeltmeler yapılmış ve 8. sınıf öğrencisi 27 öğrenciye uygulanmıştır. Elde edilen verilere Microsoft Excel programı kullanılarak madde güçlük indeksi (P) ve madde ayırt edicilik indeksi (D) değerleri hesaplanarak madde analizi yapılmıştır. Tablo 1'de madde analizi sonuçları yer almaktadır.

$\begin{aligned} & \text { Tablo 1. } \\
& \text { Madde Analizi Sonuçlart }\end{aligned}$
\begin{tabular}{ccccccccc}
\multicolumn{1}{l}{ Sadde } & $\mathbf{P}$ & $\mathbf{D}$ & Madde & $\mathbf{P}$ & $\mathbf{D}$ & Madde & P & D \\
\hline $\mathbf{1}$ & 0.48 & 0.57 & $\mathbf{1 0}$ & 0.33 & 0.57 & $\mathbf{1 9}$ & 0.07 & $0.14^{*}$ \\
$\mathbf{2}$ & 0.74 & $0.14^{*}$ & $\mathbf{1 1}$ & 0.37 & $0.00^{*}$ & $\mathbf{2 0}$ & 0.48 & 0.29 \\
$\mathbf{3}$ & 0.70 & 0.29 & $\mathbf{1 2}$ & 0.30 & 0.29 & $\mathbf{2 1}$ & 0.89 & $0.14^{*}$ \\
$\mathbf{4}$ & 0.22 & $0.00^{*}$ & $\mathbf{1 3}$ & 0.37 & 0.71 & $\mathbf{2 2}$ & 0.22 & $0.14^{*}$ \\
$\mathbf{5}$ & 0.59 & 0.43 & $\mathbf{1 4}$ & 0.41 & 0.71 & $\mathbf{2 3}$ & 0.70 & 0.57 \\
$\mathbf{6}$ & 0.74 & 0.43 & $\mathbf{1 5}$ & 0.15 & 0.29 & $\mathbf{2 4}$ & 0.82 & 0.29 \\
$\mathbf{7}$ & 0.63 & 0.57 & $\mathbf{1 6}$ & 0.11 & 0.29 & $\mathbf{2 5}$ & 0.74 & 0.57 \\
$\mathbf{8}$ & 0.78 & $0.14 *$ & $\mathbf{1 7}$ & 0.15 & $-0.14^{*}$ & & & \\
$\mathbf{9}$ & 0.70 & 0.43 & $\mathbf{1 8}$ & 0.70 & 0.29 & & & \\
\hline
\end{tabular}

Testteki 2, 4, 8, 11, 17, 19, 21, 22 numaralı soruların madde ayırt edicilik indeksi değerlerinin 0,19'un altında olduğu görülmektedir. Bu nedenle bu sorular testten çıkarılmıştır (Turgut, 1992). 3, 12, 15, 16, 18, 20,24 numaralı soruların madde ayırt edicilik değerinin 0.29 olduğu ve değiştirilerek kullanılabileceği söylenebilir. Bu sorular üzerinde genel yapısı bozulmayacak şekilde, küçük düzenlemeler yapılmıştır. Madde analizi yapılan testten sekiz madde çıkarılmıştır. Sonuç olarak test, 17 maddeden oluşan son hâlini almıştır.

Testin güvenirliğini belirlemek için Kuder-Richardson 20 [KR-20] değeri hesaplanmıştır. Çünkü testteki maddelerin madde güçlük indeksi değerleri birbirinden farklıdır (Lenke vd., 1977). Başarı testlerinin güvenirlik katsayıları, testte yer alan bütün maddelerin madde güçlükleri birbirine yakın ise KR-21, birbirinden farklı ise KR-20 formülü kullanılarak hesaplanmaktadır (Demircioğlu, 2008). Geliştirilmiş olan "Madde Konusu Yaşam Temelli Başarı Testi'nin KR-20 güvenirlik katsayısı 0.68 olarak bulunmuştur. Kehoe’e göre (1995) 10-15 civarı maddeden oluşan testlerin güvenirliğinin belirlenmesinde KR-20 güvenirlik katsayısının 0.50 olması yeterliyken, 50 maddenin üzerindeki testler için KR-20 değerinin en az 0.80 olması (maksimum 1,0) gerekmektedir. Bu nedenle sonuç olarak testinin güvenirliğinin yeterli düzeyde olduğu söylenebilir.

\subsubsection{Fen Öğrenmeye Yönelik Motivasyon Ölçeği (FÖYMÖ)}

Çalışmada öğrencilerin fen öğrenmeye karşı motivasyonlarını belirlemek amacıyla Dede ve Yaman (2008) tarafından geliştirilmiş olan Fen Öğrenmeye Yönelik Motivasyon Ölçeğiı"nden yararlanılmıştır. Ölçek 5'li Likert tipinde 23 maddeden oluşmaktadır. FÖYMÖ’nün beş alt boyutu bulunmaktadır. Bunlar "araştırma yapmaya yönelik motivasyon", performansa yönelik motivasyon", iletişime yönelik motivasyon”, işbirlikli çalışmaya yönelik motivasyon" ve "katılıma yönelik motivasyon"dur. Bu alt boyutların Cronbach Alfa güvenirlik katsayısı değerleri sırasıyla $0.75,0.68,0.56,0.55$ ve 0.59 'dur. Ölçeğin tamamına ait Cronbach Alfa güvenirlik katsayısı ise 0.80 olarak bildirilmiştir (Dede \& Yaman, 2008). Mevcut çalışmada ölçeğin tümüne ait ön test, son test ve kalıcılık testlerinin Cronbach Alfa güvenirlik katsayısı değerleri sirasıla 0.95, 0.93 ve 0.91 olarak hesaplanmiştır.

\subsubsection{Fen ve Teknoloji Dersi Özyeterlik Ölçeği (FTÖÖ)}

Çalışmada öğrencilerin fen öğrenmeye karşı özyeterliklerini belirlemek amacıyla Tatar vd. (2009) tarafından geliştirilmiş olan Fen ve Teknoloji Dersi ÖzyeterlikÖlçeği”nden faydalanılmıştır. Ölçek 5'li Likert tipinde 27 
maddeden oluşmaktadır. Ölçeğin Cronbach Alfa güvenirlik katsayısı 0.93 olarak bildirilmiştir. FTÖÖ’nün üç alt boyutu bulunmaktadır. Bunlar, "fen ve teknolojiye yönelik güven”, "fen ve teknoloji ile ilgili zorluklarla başa çıkabilme" ve "fen ve teknoloji performansına güven"dir. Bu alt boyutların Cronbach Alfa güvenirlik katsayısı değerleri sırasıyla 0.93, 0.75 ve 0.80 'dir (Tatar vd., 2009). Mevcut çalışmada ölçeğin tümüne ait ön test, son test ve kalıcılık testlerininCronbach Alfa güvenirlik katsayısı değerleri sırasıyla $0.83,0.86$ ve 0.82 olarak hesaplanmıştır.

\subsubsection{Fene Yönelik Sorgulayıcı Öğrenme Becerileri Algısı Ölçeği (FYSÖBAÖ)}

Çalışmada öğrencilerin fene yönelik sorgulayıcı öğrenme becerileri algılarını belirlemek amacıyla Balım ve Taşkoyan'ın (2007) geliştirmiş olduğu Fene Yönelik Sorgulayıcı Öğrenme Becerileri Algısı Ölçeği”nden yararlanılmıştır. Ölçek, 5'li Likert tipinde toplam 22 maddeden oluşmaktadır. Ölçeğin "olumlu algılar", "olumsuz algılar" ve "doğruluğunu sorgulama algıları" olmak üzere üç alt boyutu bulunmaktadır. Bu alt boyutların Cronbach Alfa güvenirlik katsayısı değerleri sırasıyla 0.67, 0.73 ve 0.71 'dir. Ölçeğin tümüne ait Cronbach Alfa güvenirlik katsayısı değerleri 0.84 olarak bulunmuştur (Balım \& Taşkoyan, 2007). Mevcut çalışmada ölçeğin tümüne ait ön test, son test ve kalıcılık testlerininCronbach Alfa güvenirlik katsayısı değerleri sirasıly $0.65,0.63$ ve 0.89 olarak hesaplanmıştır.

\subsubsection{Yarı yapılandırılmış öğrenci görüş formu}

Nicel veri toplama araçlarıyla elde edilen verileri destelemek ve öğrencilerin REACT stratejisi ile ilgili görüşlerini belirlemek amacıyla araştırmacılar tarafından geliştirilen yarı yapılandırılmış öğrenci görüş formu uygulamadan sonra, gönüllü olan 13 öğrenciye uygulanmıştır. Form, iki alan uzmanının görüşleri alınarak, araştırmacılar tarafından geliştirilmiştir. Formda dokuz soru yer almaktadır. Formda yer alan sorulardan bazıları şöyledir:

1. Uygulamada en çok hoşunuza giden neydi?

2. Uygulama sırasında karşılaştığınız zorluklar ya da olumsuzluklar nelerdir?

3. Uygulama sonrasında derse karşı ilginizde, tutumunuzda, motivasyonunuzda ve özyeterliğinizde bir değişiklik oldu mu? Nedenini açıklayınız?

4. Konular günlük yaşamla ilişkilendirildiğinde konuların kavranılmasında ne gibi etkisi oldu?

\subsection{Uygulama süreci}

Çalışmanın uygulama aşaması, 2017-2018 öğretim yılı güz döneminde, 28.12.2017- 18.01.2018 tarihleri arasında toplam 14 ders saati süresince yürütülmüştür. Uygulama öncesi öğrencilere yaklaşık dört ders saati süresince REACT stratejisi hakkındaayrıntılı bilgi verilmiş ve ön test olarak veri toplama araçları uygulanmıştır. Ayrıca öğrencilere araştırmacılar tarafından geliştirilen öğrenci ders materyalleri dağıtılarak, öğrencilerin uygulama süresince bu materyallerden yararlanmaları sağlanmıştır. Uygulamadansonra son test olarak veri toplama araçları ve yarı yapılandırılmış öğrenci görüş formu kullanılmıştır. Uygulamanın bitiminden sekiz hafta sonra kalıcılık testi olarak veri toplama araçları tekrar uygulanmıştır.

Uygulama için kolay ulaşılabilir örnekleme yöntemiyle araştırmacının da fen bilimleri öğretmeni olarak görev yaptığı ortaokul, uygulama okulu olarak seçilmiştir. Öğretmenden kaynaklı bir etki olmaması adına uygulamanın dersin öğretmeni tarafindan yürütülmesi uygun görülmüştür. Uygulamadan önce öğrencilere araştırmacılar tarafından hazırlanan öğrenci materyalleri dağıtılmış ve uygulama sürecinde bu materyalden yararlanılmıştır. Saf maddeler, karışımlar ve karışımların ayrılması konu başlıkları için birer bağlam hazırlanmıştır. REACT stratejisinin aşamalarına uygun olarak hazırlanan öğrenci materyalinde, her bir konu birer bağlam ile başlamakta ve daha sonra bu bağlamla ilişkili etkinlikler yer almaktadır. Ayrıca uygulamayı yapan araştırmacı da, araştırmacılar tarafından geliştirilen öğretmen ders materyalinden faydalanmıştır. Aşağıda uygulamanın bir parçası olarak, saf maddeler konusunun REACT stratejisinin basamaklarına göre işlenişi anlatılmaktadır:

1- Iliş̧kilendirme aşaması (40 dakika): Derse öğrencilerden materyallerinde yer alan "Kışa hazırlık" adlı bağlamı okumaları istenerek başlanmıştır. Öğrencilerin saf madde kavramını ilk olarak 4. sınıf fen bilimleri dersinde öğrenmiş oldukları için, öğrencilerin ön bilgilerine dayanarak bağlamda geçen maddelerin neler olduğu ve bunlardan hangilerinin saf madde olduğu sorulmuştur. Ayrica öğrencilere "Elementin yapısı nasıldır?", "Çevrenizde hangi tür elementler yer almaktadır ve sembolleri nelerdir?", "Bileşiğin yapısı nasıldır?”, “Çevrenizde yer alan bileşikler ve sembolleri nelerdir?” gibi soruları yöneltilerek bir tartışma ortamı oluşturularak öğrencilerin düşünceleri alınmıştır. 


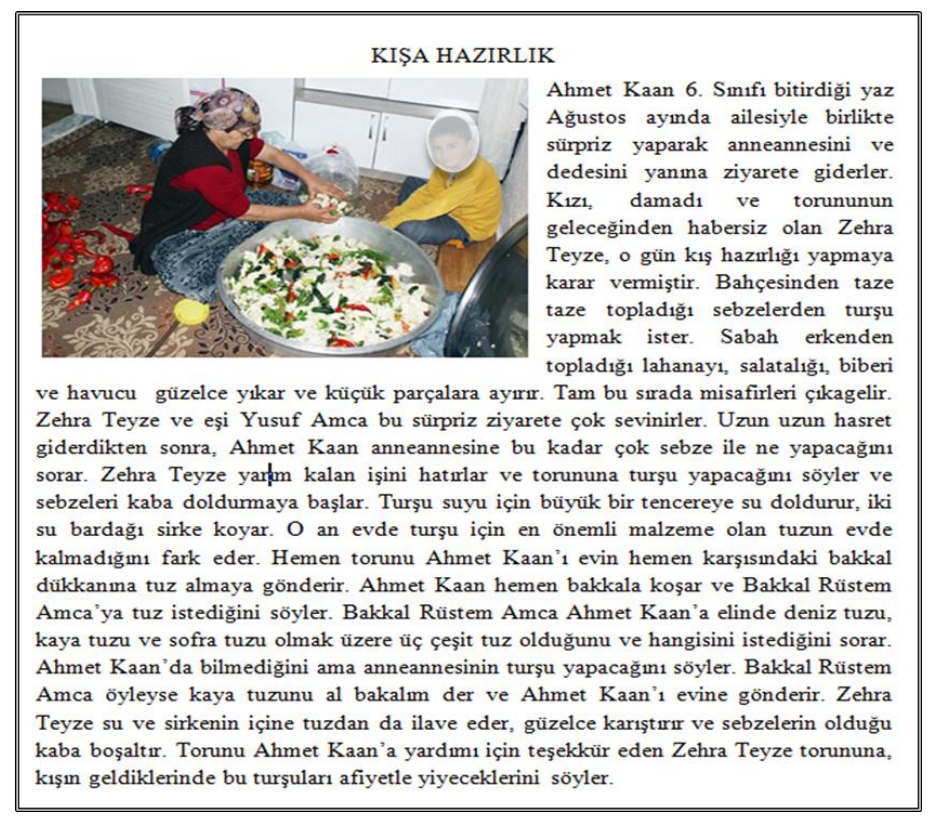

Şekil 1. “Kışa Hazırlık” adlı bağlam

2- Tecrübe etme aşaması (40 dakika): Bu aşamada öğretmen öğrencileri beşerli gruplara ayırmış ve öğrencilerden öğrenci materyalinde yer alan "iki elementten bileşik eldesi” deneyini dikkatli bir şekilde yapmalarını istemiştir. Öğretmen öğrencilerin deneyi yapışlarını izlemiş ve gerekli durumlarda öğrencilerin deneyi doğru bir şekilde yapmaları için öğrencilere rehberlik yapmıştır. Ayrıca öğretmen öğrencilerden deney sonrasında deney ile ilgili soruları cevaplamaları istemiştir. Bu sayede öğrencilerin konuyu öğrenmeleri için gerekli bilgi ve beceriyi ilk elden kazanmaları sağlanmıştır.

3- Uygulama aşaması (20 dakika): Bu aşamada öğretmen sınıfa çeşitli kurabiye ve krakerler getirmiştir. Öğrencilere bu kurabiye ve krakerlerin her birinin farklı bir elementi temsil ettiği, yani her birinin model olarak kullanılacağını söylemiştir. Öğrenciler küçük gruplara ayrılarak, öğrencilerden daha önce öğrendikleri saf maddeleri (su, amonyak, kükürt dioksit, şeker, tuz, azot, oksijen vb.) bu modellerle göstermeleri istenir. $\mathrm{Bu}$ sayede günlük yaşamdan ilgilerini çekebilecek durumlarla kavramların kullanıldığı bir ortam oluşturulur. Böylece öğrencilerin kavramları öğrenmesi ve kavramları anlaması için motive olmaları sağlanmıştır.

4- İşbirliği aşaması (40 dakika): Bu aşamada öğrencilerden grupça, sınıfa getirilen diş macunu, alüminyum folyo, gübre, yemek tuzu, uçan balon, su, seramik, deodorant, 1şıklı reklam panosu, ampul, demir çubuk, bakır çaydanlık, amonyak gibi maddeleri incelemeleri ve bu maddelerin nelerden oluştuğunu araştırarak tartışmaları istenmiştir. Yani bu aşamada öğrencilerden işbirliği içerisinde çalışmaları ve çalışma sonuçlarını arkadaşlarıyla paylaşmaları istenmiştir.

5- Transfer etme aşaması (20 dakika): Bu son aşamada öğrencilerden öğrenci materyalinde yer alan günlük hayattan kullanım alanına sahip, yaygın element ve bileşiklerin resimlerine bakmaları ve bireysel olarak resimlerde yer alan nesneleri oluşturan element ve/veya bileşiği araştırarak bulmaları istenmiştir.

Uygulama sürecinde kullanılan veri toplama araçları ve uygulanma zamanları aşağıda Tablo 2'de yer almaktadır.

\begin{tabular}{lll}
\hline $\begin{array}{l}\text { Tablo 2. } \\
\text { Veri Toplama Araçlart }\end{array}$ & Uygulama Zamanları \\
$\begin{array}{l}\text { Ön test } \\
\text { (Uygulama öncesi) }\end{array}$ & $\begin{array}{l}\text { Son test } \\
\text { (Uygulama sonrası) }\end{array}$ & $\begin{array}{l}\text { Kalıcılık testi } \\
\text { (Uygulamadan sekiz hafta sonra) }\end{array}$ \\
\hline MK-YTBT & MK-YTBT & MK-YTBT \\
FÖYMÖ & FÖYMÖ & FÖYMÖ \\
FTÖÖ & FTÖÖ & FTÖÖ \\
FYSÖBAÖ & FYSÖBAÖ & FYSÖBAÖ \\
& Yarı Yapılandırılmış Öğrenci Görüş Formu & \\
\hline
\end{tabular}

Uygulama öncesi MK-YTBT, FÖYMÖ, FTÖÖ ve FYSÖBAÖ ön test olarak uygulanmıstır. Uygulama süreci olan 14 ders saati (3,5 hafta) boyunca dersler REACT strateji kullanılarak işlenmiştir. Uygulamanın hemen sonrasında nicel veri toplama araçları olan MK-YTBT, FÖYMÖ, FTÖÖ, FYSÖBAÖ ve nitel veri toplama aracı 
olan yarı yapılandırılmış öğrenci görüş formu son test olarak kullanılmıştır. Uygulamadan sekiz hafta sonra kalıcılık testi olarak MK-YTBT, FÖYMÖ, FTÖÖ ve FYSÖBAÖ tekrar uygulanmıştır. Öğrenilen bilgi zamanla önce hızlı ve daha sonra ise çok yavaş bir şekilde unutulmaktadır (Ebbinghaus, 1885; Schultz \& Schultz, 1992/2002, s.142). Ebbinghaus'a göre, bireylerde unutma anlamsız içeriklerde çok fazla olurken, anlamlı içeriklerde daha az ve mantıksal yapı gösteren içeriklerde daha da az hızda seyretmektedir (Karagöz, 2003). Alan yazında yer alan çalışmalara bakıldığında, REACT stratejisinin öğrenmenin kalıcılı̆̆ına etkisini incelemek amaciyla daha çokdört hafta (Gül, 2016; Karslı \& Yiğit, 2017) sonra kalıcılık testlerinin uygulandığ görülmektedir. Bazı çalışmalarda da REACT stratejisinin altı (Karaş, 2019), dokuz (Ültay, 2014) ve hatta 10 haftaya (Sevinç, 2015) kadar öğrenmenin kalıcılığını sağladığı anlaşılmaktadır. Bu nedenle, bu çalışmada kalıcılık testlerinin uygulamanın bitiminden sekiz hafta sonra uygulanmasının yeterli olacağı düşünülmüştür.

\subsection{Verilerin analizi}

Çalışamadan elde edilen nicel verilerin analizinde SPSS 23.0 istatistik paket programı kullanılmıştır. MK-YTBT, FÖYMÖ, FTÖÖveFYSÖBAÖ’den elde edilen verileri setlerinin normal dağılım gösterip göstermedikleri Shapiro-Wilks testi, Q-Q Plots grafikleri, çarpıklık ve basıklık katsayı değerleri ile incelenmiştir. Veri setinin normal dağılım gösterdiği durumlarda kestirimsel istatistik yöntemlerinden bağımlı gruplar t- testi, veri setinin normal dağılım göstermediği durumlarda ise bağımlı gruplar t-testinin non-parametrik karşılığı olan Wilcoxon İşaretli Sıralar Testi kullanılmıştır (Büyüköztürk, 2009). Yapılan analizler sonucunda, FÖYMÖ ön test, son test ve kalıcılık testi verileri ile MK-YTBT kalıcılık testi verilerinin 0.05 anlamlılık düzeyine göre normal dağılmadığı belirlenmiştir.

FÖYMÖ, FTÖÖ ve FYSÖBAÖ’nün güvenirliklerini belirleme amacıyla ön test, son test ve kalıcılık testlerine ait Cronbach Alfa katsayı değerleriileMK-YTBT'nin KR-20 değeri hesaplanmıştır. Ayrıca MK-YTBT'nin kapsam geçerliğini belirlemek amacıyla hazırlanan belirtke tablosu bir fen eğitimi uzmanı ve iki fen bilimleri öğretmeninin görüşlerine sunulmuştur.

Çalışmada yarı yapılandırılmış öğrenci görüş formu ile elde edilen nitel verilerin analizi betimsel olarak analiz edilmiştir. Yapılan analize göre, görüşülen ve gözlenen bireylerin görüşlerini yansıtmak için doğrudan alıntılardan bahsedilmiştir (Yıldırım \& Şimşek, 2016, s. 239).

\section{BULGULAR}

\subsection{Birinci araştırma sorusuna ait bulgular}

REACT stratejisine dayalı öğretimin öğrencilerinin fen dersindeki akademik başarılarına etkisine ilişkin bulgular Tablo 3'de yer almaktadır.

\section{Tablo 3.}

MK-YTBT Ön Test-Son Test Ortalama Puanlarına İlişkin Bağımlı Gruplar t-Testi Sonuçları

\begin{tabular}{lcccccc}
\hline Test & $\mathbf{N}$ & $\overline{\mathbf{x}}$ & $\mathbf{S}$ & $\mathbf{s d}$ & $\mathbf{t}$ & $\mathbf{p}$ \\
\hline Ön test & 18 & 40.39 & 14.24 & \multirow{2}{*}{17} & \multirow{2}{*}{-3.710} & .002 \\
Son test & 18 & 51.78 & 14.08 & & & \\
\hline
\end{tabular}

Tablo 3 incelendiğinde; MK-YTBT ön test ve son test ortalama puanları arasında istatistikî olarak anlamlı düzeyde bir fark olduğu $(\mathrm{t}(17)=-3.710 ; \mathrm{p}<.05)$ görülmektedir. Bu sonuç bize REACT stratejisinin öğrencilerin akademik başarıları üzerinde olumlu bir etkisinin olduğunu göstermektedir. Yarı yapılandırılmış görüş formuyla elde edilmiş olan öğrenci görüşleri, elde edilen bu sonucun doğruluğunu kanıtlamaktadır. Aşağıda öğrencilerin REACT stratejiyle yapılan öğretimin akademik başarılarına olan katkılarına ilişkin görüşlerinden bazıları yer almaktadir.

“[Bu şekilde ders işlenmesi] bana göre çok iyi oldu. Birçok bilgiyi edinmiş oldum” (Ö3).

“[Derste] daha çok şey öğrendik ve konulart iyice kavrayabildik” (Ö5).

“Fen dersini zaten seviyordum. Ama bu şekilde hiç yazı okumadan, hiç çalışmadan soruları çözdüğümü gördüm. Aklıma daha iyi girdi” (Ö7).

“[Dersi] bu şekilde işlememiz daha iyi, faydalı oldu. Çünkü konuyu daha iyi anladık” (Ö8).

"Yaptı̆̆ımız deney derste daha iyi anlamamızı să̆ladı” (Ö11).

REACT stratejisinin öğrencilerin akademik başarılarının kalıcılığına etkisine ilişkin bulgulara Tablo 4'de yer verilmiştir. 
Tablo 4.

MK-YTBT Son Test-Kalıcılık Testi Ortalama Puanlarının Wilcoxon İşaretli Sıralar Testi Sonuçları

\begin{tabular}{lccccc}
\hline Son Test- Kalıcılık Testi & $\mathbf{n}$ & Sira Ortalama & Sira Toplamı & $\mathbf{Z}$ & $\mathbf{p}$ \\
\hline Negatif sıra & 5 & 12.30 & 61.50 & $-.337 *$ & .736 \\
Pozitif sıra & 11 & 6.77 & 74.50 & & \\
Eşit & 2 & - & - & & \\
\hline TOPLAM & 18 & & & \\
\hline
\end{tabular}

*Negatif siralar temeline dayalı

Tablo 4 incelendiğinde; MK-YTBT son test ve kalıcılık testi sıra ortalamaları arasında istatistikî olarak anlamlı düzeyde bir farkın bulunmadığı $(\mathrm{z}=-.337$; p>.05) anlaşılmaktadır. Bu sonuç, REACT stratejisiyle yapılan öğretimden sekiz hafta sonra, öğrencilerin başarılarında istatistiksel açıdan anlamlı bir değişiklik olmadığını ifade etmektedir. Buna dayanarak REACT stratejisinin öğrencilerin akademik başarılarının kalıcılığını sağladığ rahatça söylenebilir. Aşağıda verilen öğrenci görüşleri bu sonucu doğrular niteliktedir.

“Öğrendiğimiz konular daha kalıcı oldu” (Ö10, Ö12).

\section{2. İkinci araştırma sorusuna ilișkin bulgular}

REACT stratejisine dayalı öğretimin öğrencilerinin fen öğrenmeye karşı motivasyonlarına etkisine ilişkin bulgular Tablo 5 'de yer almaktadır.

\begin{tabular}{lccccc}
\hline Tablo 5. & \multicolumn{5}{l}{} \\
FÖYMÖ Ön Test-Son Test & Ortalama & Puanlarının Wilcoxon İsaretli Siralar Testi Sonuçlart & \\
\hline Son Test- Ön Test & $\mathbf{N}$ & Sıra Ortalama & Sira Toplamı & $\mathbf{Z}$ & $\mathbf{p}$ \\
\hline Negatif sıra & 5 & 8.10 & 40.50 & $-1.705^{*}$ & .088 \\
Pozitif sıra & 12 & 9.38 & 112.50 & \\
Eşit & 1 & - & - & \\
\hline TOPLAM & 18 & & & \\
\hline
\end{tabular}

*Negatif siralar temeline dayalı

Tablo 5 incelendiğinde; FÖYMÖ ön test ile son test sıra ortalamaları arasında istatistikî olarak anlamlı düzeyde bir farkın olmadığı $(\mathrm{z}=-1,705 ; \mathrm{p}>.05)$ görülmektedir. FÖYMÖ ön test ve son test ortalamaları arasında son test lehine \%10.75'lik artış olmasına rağmen, bu fark istatistiksel açıdan anlamlı bulunmamıştır. Bu nedenle REACT stratejisinin öğrencilerin fen dersine karşı motivasyonları üzerinde olumlu bir etkisinin olmadığı söylenebilir.

REACT stratejisine dayalı öğretimin öğrencilerinin fen öğrenmeye karşı motivasyonlarının kalıcılığına etkisine ilişkin bulgular Tablo 6'da yer almaktadır.

Tablo 6.

FÖYMÖ Son Test-Kalıcılık Testi Ortalama Puanlarının Wilcoxon Işaretli Sıralar Testi Sonuçları

\begin{tabular}{lccccc}
\hline Kalıcılık Testi- Son Test & N & Sıra Ortalama & Sira Toplamı & Z & p \\
\hline Negatif sıra & 9 & 9.00 & 81.00 & $-.196^{*}$ & .845 \\
Pozitif sıra & 9 & 10.00 & 9.00 & \\
Eşit & 0 & - & - & \\
\hline TOPLAM & 18 & & & \\
\hline
\end{tabular}

*Negatif sıralar temeline dayalı

Tablo 6 incelendiğinde; FÖYMÖ son test ile kalıcılık testi sıra ortalamaları arasında istatistikî olarak anlamlı düzeyde bir farkın bulunmadığı $(\mathrm{z}=-, 196 ; \mathrm{p}>.05)$ görülmektedir. Bu sonuç, REACT stratejisiyle öğretiminin öğrencilerin fen dersine karşı motivasyonlarının kalıcılığını sağladığını göstermektedir.

\section{3. Üçüncü araştırma sorusuna ilişkin bulgular}

REACT stratejisine dayalı öğretimin öğrencilerinin fen öğrenimi özyeterliklerine etkisine ilişkin bulgular Tablo 7 'de yer almaktadır.

Tablo 7.

FTÖÖ Ön Test-Son Test Ortalama Puanlarına İliş̧kin Bağımlı Gruplar t-Testi Sonuçları

\begin{tabular}{lllllll}
\hline Test & $\mathbf{N}$ & $\overline{\mathbf{x}}$ & $\mathbf{S}$ & $\mathbf{s d}$ & $\mathbf{t}$ & $\mathbf{p}$ \\
Ön Test & 18 & 3.35 & 0.49 & \multirow{2}{*}{17} & \multirow{2}{*}{-3.196} & \multirow{2}{*}{005} \\
Son Test & 18 & 3.85 & 0.57 & & & \\
\hline
\end{tabular}


Tablo 7'ye bakıldığında; FTÖÖ ön test ve son test ortalama puanları arasında istatistikî olarak anlamlı düzeyde bir farkın olduğu $(\mathrm{t}(17)=-3.196 ; \mathrm{p}<.05)$ görülmektedir. Bu sonuca bakılarak, REACT stratejisine dayalı öğretimin öğrencilerinin fen öğrenimi özyeterlikleri üzerinde olumlu bir etkisinin olduğu söylenebilir. Bu sonucu doğruluğunu kanıtlayan öğrenci görüşlerinden bazıları aşağıda verilmiştir.

“Derse olan ilgim daha da arttı. Neredeyse sadece bu derse girmek istedim” (Ö3).

“Kendime güvenim arttı. Çünküyapmak istediklerimi kâğıda yaptım” (Ö6).

REACT stratejisine dayalı öğretimin öğrencilerinin fen öğrenimi özyeterliklerinin kalıcılığına etkisine ilişkin bulgular Tablo 8'de yer almaktadır.

Tablo 8.

FTÖÖ Son Test-Kalıcılık Puanlarına İlişkin Bă̆ımlı Gruplar t-Testi Sonuçları

\begin{tabular}{llccccc}
\hline Test & $\mathbf{N}$ & $\overline{\mathbf{x}}$ & $\mathbf{S}$ & $\mathbf{s d}$ & $\mathbf{t}$ & $\mathbf{p}$ \\
Son Test & 18 & 3.85 & 0.57 & \multirow{2}{*}{17} & .192 & .850 \\
Kalıcılık Testi & 18 & 3.84 & 0.46 & & & \\
\hline
\end{tabular}

Tablo 8 incelendiğinde; FTÖÖ son test ve kalıcıllk testi ortalama puanları arasında istatistikî olarak anlamlı düzeyde bir farkın olmadığı $(\mathrm{t}(17)=0.192 ; \mathrm{p}>.05)$ görülmektedir. Bu sonuç, REACT stratejisinin öğrencilerin fen öğrenimi özyeterliklerinin kalıcılığını sağladığını göstermektedir.

\subsection{Dördüncü araştırma sorusuna ilişkin bulgular}

REACT stratejisine dayalı öğretimin öğrencilerin sorgulayıcı öğrenme becerisi algılarına ilişkin bulgular Tablo 9'da yer almaktadir.

Tablo 9.

FYSÖBAÖ Ön Test-Son Test Ortalama Puanlarına İlişkin Bağımlı Gruplar T-Testi Sonuçları

\begin{tabular}{llccccc}
\hline Test & $\mathbf{N}$ & $\overline{\mathbf{x}}$ & $\mathbf{S}$ & $\mathbf{S d}$ & $\mathbf{t}$ & $\mathbf{p}$ \\
\hline Ön Test & 18 & 3.95 & 0.38 & & & \\
Son Test & 18 & 4.17 & 0.35 & 17 & -2.757 & .013 \\
\hline
\end{tabular}

Tablo 9 incelendiğinde; FYSÖBAÖ ön test ve son test ortalama puanları arasında istatistikî olarak anlamlı düzeyde bir farkın olduğu $(\mathrm{t}(17)=-2.757 ; \mathrm{p}<.05)$ görülmektedir. Elde edilen bu sonuç, REACT stratejisiyle öğretimin öğrencilerin sorgulayıcı öğrenme becerilerine olumlu etkisi olduğunu göstermektedir.

REACT stratejisine dayalı öğretimin öğrencilerin sorgulayıcı öğrenme becerisi algılarının kalıcılığına etkisine ilişkin bulgular Tablo 10'da yer almaktadır.

Tablo 10.

FYSÖBAÖ Son Test-Kalıcılık Testi Ortalama Puanlarına İlişkin Bă̆ımlı Gruplar T-Testi Sonuçları

\begin{tabular}{lcccccc}
\hline Test & $\mathbf{N}$ & $\overline{\mathbf{x}}$ & $\mathbf{S}$ & $\mathbf{S d}$ & $\mathbf{t}$ & $\mathbf{p}$ \\
\hline Son Test & 18 & 4.17 & 0.35 & & & \\
Kalıcilik testi & 18 & 4.20 & 0.51 & 17 & -.289 & .776 \\
\hline
\end{tabular}

Tablo 10 incelendiğinde, FYSÖBAÖ son test ve kalıcılık testi ortalama puanları arasında istatistikî olarak anlamlı düzeyde bir farkın olmadığı $(\mathrm{t}(17)=-.289 ; \mathrm{p}>.05)$ görülmektedir. Bu sonuç, REACT stratejiyle yapılan öğretimin öğrencilerin sorgulayıcı öğrenme becerilerinin kalıcılı̆̆ına olumlu etkisi olduğunu belirtmektedir.

\section{TARTIŞMA ve SONUÇ}

Çalışmada birinci araştırma sorusuna ilişkin olarak; MK-YTBT ön test ve son test puanlarına ait ortalamalar arasında istatistiksel olarak bir fark bulunurken (Tablo 3), aynı testin son test ve kalıcılık testi puanlarına ait ortalamaları arasında (Tablo 4) istatistiksel olarak bir fark bulunmamıştır. Bu bulgu, REACT stratejisi ile yapılan öğretimin öğrencilerin akademik başarılarını artırdığını göstermektedir. Bu sonuçların elde edilmesinde, öğrencilerin küçük gruplar halinde deney yaparak kendi bilgilerini keşfetmelerinin ve öğrendiklerini uygulayabildikleri etkinliklerinin olmasının etkili olduğu söylenebilir. Alan yazında yer alan birçok çalışmada dabenzer bulguların olduğu görülmektedir (Aktaş, 2013; Ayvacı \& Bebek, 2018; Bilgin, 2015; Bilgin vd., 2017; Demircioğlu vd., 2019; Gül vd., 2017; Günter, 2018; Ingram, 2003; Karaş, 2019; Keskin \& Çam, 2018; Kumaş, 2015; Saka, 2011). Örneğin Bilgin (2015) tarafından yapılan çalışmada, REACT stratejisiyle 6. sınıf "Maddenin Yapısı ve Özellikleri" ünitesinin öğretimin öğrencilerin başarılarını artırdığı sonucuna ulaşılmıştır. Ayrıca mevcut çalışmada REACT stratejisinin öğrencilerin akademik başarılarının kalıcılığını sağladığı sonucuna da ulaşılmıştır. Elde edilen bu sonuç, alan yazında yer alan bazı çalışma sonuçlarıyla uyum göstermektedir (Gül, 2016; Karaş, 2019; Karslı \& Yiğit, 2017; Sevinç, 2015; Ültay, 2014). Yine Bilgin (2015) tarafından yapılan 
çalışmanın sonucunda RAECT stratejisinin öğrencilerde kalıcı öğrenmeyi sağladığı anlaşılmıştır. Mevcut çalışmada yarı yapılandırılmış görüş formuyla elde edilmiş olan öğrenci görüşleride REACT stratejisini öğrencilerin başarıları ve öğrenmenin kalıcılığı üzerindeki olumlu etkisini doğrular niteliktedir. Sonuç olarak gerek bu çalş̧madan gerekse alanyazından elde edilen benzer bulgular, REACT stratejisinin öğrencilerin akademik başarılarını artırması ve akademik başarının kalıcılığını sağlamasına yönelik yararını göstermesi ve fen konu ya da kavramlarının öğretiminde kullanımının artııılmasının gerekliliğini ortaya koyması açısından oldukça önemlidir.

Çalı̧̧ada ikinci araştırma sorusuna ilişkin olarak; FÖYMÖ ön test ve son test puanlarına bakıldığında son test lehine $\% 10.75^{\prime}$ lik bir artış olmasına rağmen, ortalamalar arasında istatistiksel olarak bir farklılık bulunmazken (Tablo 5), aynı testin son test ve kalıcılık testi puanlarına ait ortalamalar arasında da (Tablo 6) istatistiksel olarak bir farklılık bulunmamıștır. Bu bulgular, REACT stratejisinin öğrencilerin motivasyonlarını artırmazken, mevcut motivasyonlarının kalıcılığını sağladığını göstermektedir. Bu sonucun elde edilmesinde, öğrencilerin zaten uygulamadan önceki motivasyon ortalamalarının iyi düzeyde olmasının ve uygulama süresinin olumlu bir etki oluşturabilecek kadar uzun olmamasının etkili olduğu düşünülmektedir. Alanyazın incelendiğinde, REACT stratejisini öğrencilerin motivasyonlarını artırmadığı sonucunu destekleyen çalıșmalara rastlanmaktadır (Gül, 2016; Gül vd., 2017; Karaş, 2019). Örneğin Karaş (2019) tarafindan yapılan çalışmada, REACT stratejisiyle 7. sınıf 'Hücre ve Bölünmeler' ünitesinin öğretiminin öğrencilerin motivasyonları açısından pozitif yönde bir anlamlı bir artış sağlamamasına rağmen negatif yönde bir değişiminde neden olmadığı bildirilmiştir. Yine bir başka çalışmada, Gül vd. (2017) REACT stratejisiyle 10. sınıf boşaltım sistemi ünitesinin öğretiminin öğrencilerin motivasyonları üzerinde olumlu bir etki oluşturmadığı sonucunu bildirmiştir. Fakat alanyazında mevcut çalışmada elde edilen sonucun tam tersi olarak, REACT stratejisinin öğrencilerin motivasyonları üzerinde olumlu etkisini bulunduğu çalışmalar da mevcuttur (Demircioğlu vd., 2019; Ingram, 2003). Örneğin Demircioğlu vd. (2019) çalı̧̧malarında, REACT stratejiyle 10. sınıf hazır gıdalar konusu işlendiğinde öğrencilerin kimya dersine karşı motivasyonlarının arttığı tespit edilmiştir.

Çalışmada üçüncü araştırma sorusuna ilişkin olarak; FTÖÖ ön test ve son test puanlarına ait ortalamalar arasında istatistiksel olarak bir farklılı bulunurken (Tablo 7), aynı testin son test ve kalıcılık testi puanlarına ait ortalamalar arasında (Tablo 8) istatistiksel olarak bir farklılık bulunmamıştır. Elde edilen bu bulguya göre, REACT stratejisinin öğrencilerin fen öğrenimi özyeterliklerini artırdığı ve fen öğrenimi özyeterliklerinin kalıcılığını sağladığı anlaşılmaktadır. Benzer şekilde Sevinç (2015)'in yapmış olduğu çalışmada da, REACT stratejisinin öğrencilerin özyeterlikleri üzerinde olumlu etkisinin olduğu sonucuna ulaşılmıştır. Mevcut çalışmada bu sonucun elde edilmesinde REACT stratejisinin ilişkilendirme aşamasında kullanılan gerçek yaşamdan bağlamların öğrencilerin ilgisini konuya çekmeyi başarmasının ve tecrübe etme aşamasında küçük gruplar halinde yaptırılan deneylerin etkili olduğu düşünülmektedir. Yarı yapılandırılmış görüş formuyla elde edilen öğrenci görüşlerinden bazıları, bu sonucun doğruluğunu destekler niteliktedir. "Sinıf içerisinde uygulamış olduğumuz deney bize katkıda bulundu. Çünkü derse olan motivasyonum arttı" (Ö3). "Günlük yaşamda konular anlatılınca o konuyu anllyorum ve günlük yaşamda da yapabiliyorum" (Ö5). "Kendime güvenim arttı. Çünkü yapmak istediklerimi kâğlda yaptım" (Ö6). "Deney ögretmenin anlattı̆̆ konuyu somutlaştırdı ve daha iyi oldu" (Ö9). "[Deneylerle] ögretmenin anlattıların daha iyi öğrendim" (Ö10). "Günlük hayattan öğrendiklerimle konuyu daha iyi ögreniyorum" (Ö10).

Çalışmada dördüncü araştırma sorusuna ilişkin olarak; FYSÖBAÖ ön test ve son test puanlarına ait ortalamalar arasında istatistiksel olarak bir fark bulunurken (Tablo 9), aynı testin son test ve kalıcılık testi puanlarına ait ortalamalar arasında (Tablo 10) istatistiksel olarak bir fark bulunmamıştır. Elde edilen bu bulguya göre, REACT stratejisi ile yapılan öğretimin öğrencilerin sorgulayıcı öğrenme becerisi algılarını artırdığ ve sorgulayıc1 öğrenme becerisi algılarının kalıcılığını sağladığı anlaşılmaktadır. Mevcut çalışmada öğrencilerin FYSÖBAÖ ön test ortalamalarının iyi düzeyde olmasına rağmen, son test ortalamalarında iyi bir artı̧ıı olduğu ve bu artışın istatistiksel olarak anlamlı bulunduğu görülmektedir. Bu sonucun elde edilmesinde REACT stratejisinin işbirliği aşamasında grupça ve transfer etme aşamasında bireysel olarak konu ile ilgili araştırmaya yönlendirilmesinin etkisinin olduğu rahatlıkla söylenebilir. Alanyazın incelendiğinde, elde edilen bu bulgularla örtüş̧en çalışmaya rastlanmazken, tam tersi bulguların elde edildiği çalışmaların bulunduğu görülmektedir (Gül, 2016; Gül vd., 2017). Örneğin Gül (2016) yapmış olduğu çalışmada,11. sınıf biyoloji dersi fotosentez konusunu REACT stratejisiyle öğretiminin öğrencilerin sorgulayıcı öğrenme becerileri algıları üzerinde önemli ölçüde bir artı̧̧a neden olmadığ̣ sonucuna ulaşmıştır. Benzer şekilde Gül vd. (2017) tarafından yapılan çalışmada da, REACT stratejisiyle 10. sınıf boşaltım sistemi ünitesinin öğretimi yapılmış ve çalışmanın sonucunda REACT stratejisinin öğrencilerinin sorgulayıcı öğrenme becerileri algıları üzerinde istatistiksel olarak anlamlı bir etkisinin olmadığı ortaya çıkmıştır.

Sonuç olarak, REACT stratejisinin öğrencilerin fen dersindeki akademik başarılarının artırılmasında ve akademik başarılarının kalıcılığının sağlanmasında; fen öğrenmeye karşı motivasyonlarının kalıcıllğının sağlanmasında; öğrencilerinin fen öğrenimi özyeterliklerinin geliştirilmesinde ve fen öğrenimi özyeterliklerinin 
kalıcılığının sağlanmasında; öğrencilerin sorgulayıcı öğrenme becerisi algılarının geliştirilmesinde ve sorgulayıcı öğrenme becerisi algılarının kalıcılığının sağlanmasında etkili olduğu tespit edilmiştir. Fakat bunla birlikte, REACT stratejisinin öğrencilerin fen öğrenmeye karşı motivasyonlarının geliştirilmesinde etkili olmadığ sonucuna da ulaşılmıştır.

Çalışma sonucunda REACT stratejisinin 7. sınıf öğrencilerinin fen bilgisi dersi "saf maddeler, karışımlar ve karışımların ayrılması” konusundaki başarılarını artırdığı ve başarılarının kalıcılığını sağladığı belirlenmiştir. Bu nedenle söz konusu stratejinin farklı fen konularına da uygulanması tavsiye edilebilir.

REACT stratejisinin öğrencilerin başarı, motivasyon, özyeterlik ve sorgulayıcı öğrenme algısı üzerindeki etkisi incelenmiştir. Her ne kadar durum çalışması bilimsel genellemelere izin vermese de (Yin, 2003, s.10), mevcut çalışmadan elde edilen sonuçlara göre REACT stratejisi öğrencilerin başarı, özyeterlik, sorgulayıcı öğrenme algısı becerilerini artırma ve ayrıca başarı, motivasyon, özyeterlik ve sorgulayıcı öğrenme algısı becerilerinin kalıcılığını sağlama konusunda etkili olduğu söylenebilir. Bu konuda ileri yapılacak olan çalışmalarda REACT stratejisinin öğrencilerin ilgi, tutum, kaygı düzeyi ve problem çözme becerisi gibi farklı bağımlı değişkenler üzerindeki etkisi de incelenebilir.

Ayrıca çalışmada REACT stratejisinin öğrencilerin fen bilimleri dersine karşı motivasyonları üzerinde istatistiksel olarak bir farkın olmadığı da sonucuna ulaşılmıştır. Mevcut çalışmanın uygulama süresi 14 ders saati olup, motivasyon gibi duyuşsal bir özelliğin değişmesi için yeterli değildir. Daha uzun süreli yapılacak olan çalışmalarla REACT stratejisinin öğrencilerin motivasyonları üzerindeki gerçek etkisi belirlenebilir. 


\section{KAYNAKÇA}

Aktaş, L. (2013). Maddenin tanecikli yapısı ve ısı konusunda REACT öğretim stratejisine yönelik geliştirilen bilgisayar destekli öğretim materyalinin öğrenci başarısına etkisi [Yayımlanmamış yüksek lisans tezi]. Karadeniz Teknik Üniversitesi.

Akyol, S. (2011). Sosyal yapılandırmacı öğrenme ortamı tasarımının öğrenenlerin akademik başarılarına ve ögrenmenin kalıcllı̆̆ına etkisi (ilköğretim 5. sinıf fen ve teknoloji dersi) [Yayımlanmamış yüksek lisans tezi]. Yıldız Teknik Üniversitesi.

Ayvacı, H. Ş. \& Bebek, G. (2018). REACT stratejisine göre hazırlanmış rehber materyalin öğrenci başarısına etkisi: Katı basıncı konusu. Adnan Menderes Üniversitesi Eğitim Bilimleri Dergisi, 9(1), 71-83.

Ayvacı, H. Ş., Er-Nas, S. \& Dilber, Y. (2016). Bağlam temelli rehber materyallerin öğrencilerin kavramsal anlamaları üzerine etkisi: "Iletken ve yalıtkan maddeler" örneği. Yüzüncü Yll Üniversitesi Eğitim Fakültesi Dergisi, 13(1), 51-78.

Bächtold, M. (2013). What do students "construct" according to constructivism in science education? Research in Science Education, 43(6), 2477-2496. https://doi.org/10.1007/s11165-013-9369-7

Bakaç, E. (2019). Comparison of 2005 science and technology curriculum, 2013 and 2018 science course curriculums. Journal of Human Sciences, 16(3), 857-870. https://doi:10.14687/jhs.v16i3.5386

Balım, G. A. \& Taşkoyan, N. S. (2007). Fene yönelik sorgulayıcı öğrenme becerileri algısı ölçeğinin geliştirilmesi. Dokuz Eylül Üniversitesi, Buca Eğitim Fakültesi Dergisi, 21, 58-63.

Barker, V., \& Millar, R. (1999). Students' reasoning about basic chemical reactions: What changes occur during a context-based post-16 chemistry course? International Journal Science Education, 21(6), 645-665.

Bennett, J., Gräsel, C., Parchmann, I., \& Waddington, D. (2006). Context-based and conventional approaches to teaching chemistry: Comparing teachers' views. International Journal of Science Education, 27(13), 1521-1547. https://doi:10.1080/09500690500153808

Bennett, J., \& Lubben, F. (2006). Context-based chemistry: The Salters approach. International Journal of Science Education, 28(9), 999-1015. https://doi.org/10.1080/09500690600702496

Bilgin, A. K. (2015). "Maddenin yapısl ve özellikleri" ünitesi kapsamında REACT stratejisine yönelik tasarlanan ögretim materyallerinin etkililiğinin değerlendirilmesi [Yayımlanmamış doktora tezi]. Karadeniz Teknik Üniversitesi.

Bilgin, A. K. \& Yiğit, N. (2017). Öğrencilerin "maddenin tanecikli yapısı" konusu ile bağlamları ilişkilendirme durumlarının incelenmesi. Mersin University Journal of the Faculty of Education, 13(1), 303-322. https://doi.org/10.17860/mersinefd.306003

Bodner, G. M. (1986). Constructivism: A theory of knowledge. Journal of Chemical Education, 63(10), 873878. https://doi.org/10.1021/ed063p873

Bilgin, A. K., Yürükel, F. N. D., \& Yiğit, N. (2017). The effect of a developed REACT strategy on the conceptual understanding of students: "Particulate nature of matter". Journal of Turkish Science Education, 14(2), 65-81. https://doi.org/10.12973/tused.10199a

Bulte, A. W. M., Westbroek, H., De Jong, O., \& Pilot, A. (2006). A research approach to designing chemistry education using authentic practices as contexts. International Journal of Science Education, 28(9), 1063-1086. https://doi.org/10.1080/09500690600702520

Büyüköztürk, Ş. (2009). Sosyal bilimler için veri analizi el kitabı. Pegem Yayınları.

CORD. (1999). Teaching science contextually. CORD Communications, Inc.

Coştu, S. (2009). Matematik öğretiminde bağlamsal ögrenme ve ögretme yaklaşımına göre tasarlanan öğrenme ortamlarında öğretmen deneyimleri [Yayımlanmamış yüksek lisans tezi]. Karadeniz Teknik Üniversitesi.

Crawford, M. L. (2001). Teaching contextually: Research, rationale, and techniques for improving student motivation and achievement in mathematics and science. CCI Publishing.

Crawford, M. L., \& Witte M. (1999). Strategies for mathematics: Teaching in context. Educational Leadership, 57(3), 34-38.

Çalık, M. \& Ültay, N. (2011). Asitler ve bazlar konusu ile ilgili örnekler üzerinden 5E modelini ve REACT stratejisini ayırt etmek. Necatibey Eğitim Fakültesi, Elektronik Fen ve Matematik Eğitimi Dergisi, $5(2), 199-220$.

Çetin, O. \& Günay, Y. (2007). Fen öğretiminde yapılandırmacılık kuramının öğrencilerin başarılarına ve bilgiyi yapılandırmalarına olan etkisi. Eğitim ve Bilim, 32(146), 24-38.

De Jong, O. (2008). Context-based chemical education: How to improve it. Chemical Education International, $8(1), 1-7$.

De Vos, W., Bulte, A. M. W., \& Pilot, A. (2002). Chemistry curricula for general education: Analysis and elements of a design. J. K. Gilbert, O. De Jong, R. Justi, D. F. Treagustand \& J. H. Van Driel (Eds.), Chemical education: Towards research-based practice (pp. 101-124). Kluwer Academic Press. 
Dede, Y. \& Yaman, S. (2008). Fen öğrenmeye yönelik motivasyon ölçeği: Geçerlik ve güvenirlik çalışması. Necatibey Eğitim Fakültesi, Elektronik Fen ve Matematik Eğitimi Dergisi (EFMED), 2(1), 19-37.

Değermenci, A. (2009). Bă̆lam temelli dokuzuncu sınıf dalgalar ünitesine yönelik materyal geliştirme, uygulama ve değerlendirme [Yayımlanmamış yüksek lisans tezi]. Karadeniz Teknik Üniversitesi.

Demirci Güler, M. P. (2008). Sınıf öğretmeni adaylarının fen ve teknoloji dersinde öğrenilmesi gereken en önemli konunun ne olduğuna ilişkin düşünceleri (Kırşehir İli örneği). Ahi Evran Üniversitesi Kırşehir Eğitim Fakültesi Dergisi (KEFAD), 9(1), 113-121.

Demircioğlu, H., Aslan, A., Açıkgöz, D., Karababa, Y. \& Güven, O. (2019). REACT stratejisinin öğrencilerin akademik başarıları ve motivasyonları üzerindeki etkisi. Journal of International Social Research, 12(64), 547-561. http://dx.doi.org/10.17719/jisr.2019.3377

Demircioğlu, H., Vural, S. \& Demircioğlu, G. (2012). "REACT" stratejisine uygun hazırlanan materyalin üstün yetenekli öğrencilerin başarısı üzerine etkisi. Ondokuz Mayıs Üniversitesi, Eğitim Fakültesi Dergisi, 31(2), 101-144.

Demircioğlu, H. (2008). İçeriğe dayalı yaklaşımın sınıf öğretmeni adaylarının maddenin halleri konusuna yönelik başarıları üzerine etkisi [Yayımlanmamış doktora tezi]. Karadeniz Teknik Üniversitesi.

Demircioglu, H., Asik, T. \& Yilmaz, P. (2019). REACT stratejisine dayalı öğretimin etkisi: 'Su arıtımı ve suyun sertliği’. International Journal of Scientific and Technological Research, 5(2), 104-118.

Ebbinghaus, H. (1885). Memory: A contribution to experimental psychology. http://psychclassics.yorku.ca/Ebbinghaus/memory6.htm

Erdem, E., Yılmaz, A., Atav, E. \& Gücüm, B. (2004). Öğrencilerin 'madde' konusunu anlama düzeyleri, kavram yanılgıları, fen bilgisine karşı tutumları ve mantıksal düşünme düzeylerinin araştırılması. Hacettepe Üniversitesi Eğitim Fakültesi Dergisi, 27(27), 74-82.

Fadhilah, R. (2017). Efektivitas model pembelajaran REACT terhadap self efficacy dan kemampuan pemecahan masalah pada materi segi empat siswa kelas VII mtsn Karanggede tahun pelajaran 2016/2017. [Unpublished doctoral dissertation]. Islam Negeri Walisongo Semarang University.

Fosnot, C. T. (1996). Constructivism: Theory, perspectives and practice. Teachers College Press.

Gilbert, J. K. (2006). On the nature of "context" in chemical education. International Journal of Science Education, 28(9), 957-976. https://doi.org/10.1080/09500690600702470

Gilbert, J. K., De Jong, O., Justi, R., Treagust, D. F., \& Van Driel, J. H. (2002). General preface. J. K. Gilbert, O. De Jong, R. Justi, D. F. Treagust \& J. H. Van Driel (Eds.), Chemical education: Towards researchbased practice (pp.xi-xiv). Kluwer Academic Publishers.

Gül, Ş. (2016). Yaşam temelli öğretim modeliyle "fotosentez" konusunun öğretimi: REACT stratejine dayalı bir uygulama. Necatibey Eğitim Fakültesi, Elektronik Fen ve Matematik Eğitimi Dergisi, 10(2), 21-45. https://doi.org/10.17522/balikesirnef.273962

Gül, Ş., Yalmancı, S. G. \& Yalmancı, E. (2017). Boşaltım sistemi konusunun öğretiminde REACT stratejisinin etkisi. Kastamonu Üniversitesi Ĕgitim Dergisi 25(1), 79-96.

Günter, T. (2018). The effect of the REACT strategy on students' achievements with regard to solubility equilibrium: Using chemistry in contexts. Chemistry Education Research and Practice, 19(4), 12871306. https://doi.org/10.1039/C8RP00087E

House, J. D. (1996). Student expectancies and academic self-concept as predictors of science achievement. Journal of Psychology, 130(6), 679-682. https://doi.org/10.1080/00223980.1996.9915041.

Ingram S. J. (2003). The effects of contextual learning instruction on science achievement male and female tenth grade students [Yayımlanmamış doktora tezi]. University South of Alabama.

Kalaycı, Ş. (2009). SPSS uygulamalı çok değişkenli istatistik teknikleri. Asil Yayınevi.

Karaduman, H., \& Gültekin, M. (2007). The effect of constructivist learning principles based learning materials to students' attitudes, success and retention in social studies. The Turkish Online Journal of Educational Technology, 6(3), 98-112.

Karaer, H. (2007). Sınıf öğretmeni adaylarının madde konusundaki bazı kavramların anlaşılma düzeyleri ile kavram yanılgılarının belirlenmesi ve bazı değişkenler açısından incelenmesi. Kastamonu Ĕ̆itim Dergisi, 15(1), 199-210.

Karagölge, Z. \& Ceyhun, İ. (2002). Öğrencilerin bazı kimyasal kavramları günlük hayatta kullanma becerilerinin tespiti. Kastamonu Eğitim Dergisi, 10(2), 287-290.

Karagöz, S. (2003). Öğrenme sürecinin temel unsuru olan tekrar işleminin yapılabilmesi için sorgular hazırlarken elektronik-kitab'ın hızından yararlanmak. Sakarya University Journal of Science, 7(3), 167-172.

Karaman, P. \& Karaman, P. (2016). Fen bilimleri öğretmenlerinin yenilenen fen bilimleri öğretim programına yönelik görüşleri. Erzincan Üniversitesi Eğitim Fakültesi Dergisi, 18(1), 243-269. https://doi.org/10.17556/jef.65883 
Karamustafaoğlu, O., Tezel, Ö. \& Sarı, U. (2018). REACT stratejisine dayalı bağlam temelli fen öğretimi. O. Karamustafaoğlu \& G. Sontay (Ed.), Güncel yaklaşım ve yöntemlerle etkinlik destekli fen ögretimi içinde (1. Bask1, s. 198-216). Pegem Akademi Yayınc1lık. https://doi.org/10.14527/ 9786052412589

Karaş, Ö. E. (2019). 7. sınıf hücre ve bölünmeler ünitesinin react stratejisiyle ögretimi [Yayımlanmamış yüksek lisans tezi]. Atatürk Üniversitesi.

Karaş, Ö. E. \& Gül, Ş. (2019). 'Hücre ve bölünmeler 'ünitesinin REACT stratejisiyle öğretiminin tutum ve motivasyona etkisi. Uluslararast Türk Eğitim Bilimleri Dergisi, 7(13), 30-50. https://doi.org/10.46778/goputeb.578264

Karslı-Baydere, F. \& Aydın, E. (2019). Bağlam temelli yaklaşımın açıklama destekli REACT stratejisine göre 'göz' konusunun öğretimi. Gazi Üniversitesi Ĕ̌̆itim Fakültesi Dergisi, 39(2), 755-791.

Karsli, F., \& Yigit, M. (2017). Effectiveness of the REACT strategy on 12th grade students' understanding of the alkenes concept. Research in Science \& Technological education, 35(3), 1-18. https://doi.org/10.1080/02635143.2017.1295369

Keengwe, J., \& Onchwari, G. (2011). Fostering meaningful student learning through constructivist pedagogy and technology integration. International Journal of Information and Communication Technology Education, 7(4), 1-10. https://doi.org/10.4018/jicte.2011100101

Kehoe, J. (1995). Basic item analysis for multiple-choice tests. Practical Assessment, Research \& Evaluation, 4(10), 1-3.

Keskin, F. \& Çam, A. (2019). Yaşam temelli REACT stratejisinin altıncı sınıf öğrencilerinin akademik başarısına ve fen okuryazarlığına etkisi. Mehmet Akif Ersoy Üniversitesi Eğitim Fakültesi Dergisi, 2019(49), 38-59. https://doi.org/10.21764/maeuefd.375043

Kumaş, A. (2015). Fizik ögretiminde REACT öğretim stratejisine dayalı olarak geliştirilen yenilikçi teknoloji destekli zenginleştirilmiş ögretmen rehber materyallerinin değerlendirilmesi [Yayımlanmamış doktora tezi]. Karadeniz Teknik Üniversitesi.

Kutu, H. (2011). Yaşam temelli ARCS ögrretim modeliyle 9. sınıf kimya dersi "hayatımızda kimya” ünitesinin ögretimi [Yayımlanmamış doktora tezi]. Atatürk Üniversitesi.

Kutu, H. \& Sözbilir, M. (2011). Yaşam temelli ARCS öğretim modeliyle 9. sınıf kimya dersi "hayatımızda kimya" ünitesinin öğretimi. Ondokuz Mayıs Üniversitesi, Eğitim Fakültesi Dergisi, 30(1), $29-62$.

Lenke, J. M., Wellens, B., \& Oswald, J. H. (1977, April 4-8). Differences between Kuder-Richardson formula 20 and formula 21 reliability coefficients for short tests with different item variabilities [Conference presentation]. Annual Meeting of the American Educational Research Association, New York, United States.

McMillan, J. H., \& Schumacher, S. (2016). Research in education: A conceptual introduction. Pearson Education, Inc.

Milli Eğitim Bakanlığı [MEB]. (2007). Ortaöğretim 9. sınıf kimya dersi öğretim programı. Talim ve Terbiye Kurulu Başkanlığı.

Milli Eğitim Bakanlığı [MEB]. (2013). İlköğretim kurumları (ilkokullar ve ortaokullar) fen bilimleri dersi (3, 4, 5, 6, 7 ve 8. sinıflar) öğretim programı. Talim ve Terbiye Kurulu Başkanlığı.

Mertler, C. A., \& Vannatta, R. A. (2005). Advanced and multivariate statistical methods: Practical application and interpretation (3rd edition). Pyrczak Publishing.

Navarra, A. (2006). Achieving pedagogical equity in the classroom. CORD Publishing.

Oguz, A. (2008). The effects of constructivist learning activities on trainee teachers' academic achievement andattitudes. World Applied Sciences Journal, 4(6), 837-848.

Osborne, J., \& Collins, J. (2001). Pupils' views of the role and value of the science curriculum: A focus-group study. International Journal of Science Education, 23(5), 441-467. https://doi.org/10.1080/09500690010006518

Özarslan, M. \& Bilgin, I. (2016). Öğrencilerin alan bağımlı/bağımsız bilişsel stillerinin ve bilimsel düşünme yeteneklerinin maddenin doğası kavramlarını anlamalarına ve fen dersine yönelik tutumlarına etkisi. Mustafa Kemal Üniversitesi Sosyal Bilimler Enstitüsü Dergisi, 13(33), 94-110.

Özmen, H. (2003). Kimya öğretmen adaylarının asit ve baz kavramlarıyla ilgili bilgilerini günlük olaylarla ilişkilendirebilme düzeyleri. Kastamonu Ĕ̌itim Dergisi, 11(2), 317-324.

Perkins, D. (1999). The many faces of constructivism. Educational Leadership, 57(3), 6-11.

Pilot, A., \& Bulte, A. M. W. (2006). Why do you "need to know"? Context-based education. International Journal Science Education, 28(9), 953-956. https://doi.org/10.1080/09500690600702462

Ramsden, J. M. (1997). How does a context-based approach influence understanding of key chemical ideas at 16+? International Journal of Science Education, 19(6), 697-710.

Schultz, D., \& Schultz, S. (2002). Modern psikoloji tarihi (Y. Aslay, Çev.). Kaknüs Yayınları. (Orjinal kaynak 1992 yılında yayımlanmıştır)

Saka, A. Z. (2011). Investigation of student-centered teaching applications of physics student teachers. Eurasian Journal of Physics and Chemistry Education, 1(1), 51-58. 
Sevinç, B. (2015). Asitler ve bazlar konusunda REACT stratejisine göre materyallerin geliştirilmesi ve etkililiğinin araştırılması [Yayımlanmamış doktora tezi]. Karadeniz Teknik Üniversitesi.

Souders, J. (1999, July 9). Contextually based learning: Fad or proven practice [Conference presentation]. American Youth Policy Forum, Capitol, Hill, Unites States.

Sözbilir, M., Sadi, S., Kutu, H., \& Yıldırım, A. (2007, 20-22 Haziran). Kimya eğitiminde içeriğge/bağlama dayalı (context-based) ögretim yaklaşımı ve dünyadaki uygulamaları [Konferans Sunumu]. I. Ulusal Kimya Eğitimi Kongresi, İstanbul, Türkiye.

Stake, R. (2003). Case studies. In N. Denzin \& Y. S. Lincoln (Eds.), Strategies of qualitative inquiry (pp. $134-$ 164). Sage.

Stolk, M. J., Bulte, A. W. M., De Jong, O., \& Pilot, A. (2009). Towards a framework for a professional development programme: Empowering teachers for context-based chemistry education. Chemistry Education Research and Practice, 10, 164-175. https://doi.org/10.1039/b908255g

Tabachnick, B. G., \& Fidell, L. S. (2013). Using multivariate statistics (6th ed.). Pearson Education.

Tanner, C. K., \& Chism, P. J. (1996). The effects of administrative policy on mathematics curricula, student achievement, and attitudes. The High School Journal, 79(4), 315-323.

Tatar, N., Yıldız, E., Akpınar, E., \& Ergin, Ö. (2009). A study on developing a self efficacy scale towards science and technology. Eurasian Journal of Educational Research (EJER), 36, 263-280.

Turgut, M. F. (1992). Ĕ̌itimde ölçme ve değerlendirme. Saydam Matbaacılık.

Ültay, E. (2014). İtme, momentum ve çarpışmalar konusuyla ilgili bağlam temelli ögrenme yaklaşımına dayalı açıklama destekli REACT stratejisine göre geliştirilen etkinliklerin etkisinin araştırılması [Yayımlanmamış doktora tezi]. Karadeniz Teknik Üniversitesi.

Ültay, E., \& Alev, N. (2017). Investigating the effect of the activities based on explanation assisted REACT strategy on learning impulse, momentum and collisions topics. Journal of Education and Practice, 8(7), 174-186.

Ültay, E., Ültay, N. \& Usta, N. D. (2018). Sınıf öğretmeni adaylarının "basit elektrik devreleri” konusunda 5E modeli ve REACT stratejisine uygun hazırladıkları ders planlarının incelenmesi. Kastamonu Ĕgitim Dergisi, 26(3), 855-864. https://doi.org/10.24106/kefdergi.413382

Ültay, N. (2012). Asit ve baz konusuyla ilgili REACT stratejisine ve 5E modeline göre etkinliklerin geliştirilmesi, uygulanması ve karşılaştırılması [Yayımlanmamış doktora tezi]. Karadeniz Teknik Üniversitesi.

Ültay, N. \& Çalık, M. (2011). Asitler ve bazlar konusu ile ilgili örnekler üzerinden 5E modelini ve REACT stratejisini ayırt etmek. Necatibey Ĕgitim Fakültesi Elektronik Fen ve Matematik Ĕ̈itimi Dergisi, 5(2), 199-220.

Ültay, N., Durukan, Ü. G., \& Ültay, E. (2015). Evaluation of the effectiveness of conceptual change texts in the REACT strategy. Chemistry Education Researchand Practice, 16(1), 22-38.

Wang, H. J. (2013, June 8-9). Practice and exploration of the dual-track project teaching method in university teaching [Conference presentation]. Conference on Education Technology and Management Science (ICETMS 2013), China.

Wilson, B. G. (1996). Constructivist learning environments: Case studies in instructional design. Educational Technology.

Yıldırım, A. \& Şimşek, H. (2016). Sosyal bilimlerde nitel araştırma yöntemleri (10. Baskı). Seçkin Yayıncılık.

Yıldırım, N. \& Konur, K. (2014). Fen bilgisi öğretmen adaylarının kimya kavramlarını günlük hayatla ilişsilendirebilmelerine yönelik gelişimsel bir araştırma. The Journal of Academic Social Science Studies, 30, 305-323. http://dx.doi.org/10.9761/JASSS2608

Yiğit, M. (2015). 12. sınıf öğrencilerinin hidrokarbon bileşikleri konusundaki kavramsal anlamalarına, bağlam temelli öğrenme yaklaşımının REACT stratejisine göre hazırlanmış materyallerin etkisi [Yayımlanmamış yüksek lisans tezi]. Giresun Üniversitesi.

Yin, R. K. (2003). Case study research design and methods (3th ed.). Sage Publications. https://doi.org/10.3138/cjpe.30.1.108 


\section{EXTENDED ABSTRACT}

\section{Introduction}

The fast development and progress of science and technology necessitated the development of learning and teaching processes. The necessity of raising generations that can keep up with the rapidly developing science and technology and contribute to the development of science and technology has made the use of more effective learning and teaching approaches and theories a necessity (Karaman \& Karaman, 2016). All around the world, constructivist learning approach has become the starting point of many educational reforms by standing out among the other approaches since the 1980s (Bächtold, 2013; Fosnot, 1996; Wang, 2013; Wilson, 1996).

Students reconstruct the existing information by harmonizing the information they will learn and use the information they have learned to solve the problems they face in their daily life (Bodner, 1986; Perkins, 1999). It is seen that constructivist approach provides meaningful and permanent learning in students but it is not possible to solve the problem of associating science subjects with daily life (Gilbert, 2006; Karagölge \& Ceyhun, 2002; Özmen, 2003; Stolk et al., 2009; Y1ldırım \& Konur, 2014). In order to overcome this problem, contextbased teaching approach is to show students the concepts of science through daily life events and thus to increase students' motivation towards science and to make them aware of the relationship between science and daily life (Sözbilir et al., 2007).

In order to apply context-based teaching approach in the classroom, it is necessary to support it with a teaching and teaching model. REACT strategy is used to integrate learning-teaching process in life-based teaching approach (Sevinç, 2015). The REACT strategy consists of five steps (Crawford, 2001; Crawford \& Witte, 1999). Ültay and Çalık (2011) describe the five steps and characteristics of the REACT strategy as follows:

1. Relating: The new subject or concept to be taught is related to the events or preliminary information that the students know from daily life.

2. Experiencing: Students are experienced through problem solving, project or laboratory activities and construct the knowledge they have learned. In this way, students learn abstract events by modeling in a concrete way. The teacher guides the students in this step.

3. Applying: Students are taught the concepts by problem solving, projects or laboratory activities. In this step, an environment in which concepts are used with realistic events in their lives, logical and situations that may be of interest should be created. In this way, students adapt to understand the concepts.

4. Cooperating: At this stage, students work in groups to collaborate to solve problems or produce solutions or research into realistic scenarios from their lives. Each student in the group has a task and each student tries to do his / her task in the best way. Also, each group of students can exchange ideas with other groups of students and take a look at their work.

5. Transferring: Students who are acquiring new knowledge are expected to use this knowledge in new situations they have not encountered before. In order to make it easier for them to transfer this new knowledge to new situations, students can have a discussion or a project assignment.

With the REACT strategy, it is believed that students' science skills can find solutions in assessing themselves, their environment and lives, and in solving the problems and problems they face in daily life. Because a teacher who uses this strategy will provide a learning environment that all students can learn (Navarra, 2006; Ültay \& Çalık, 2011).

REACT strategy is increasingly used in science education (Coştu, 2009; Crawford, 2001; Crawford \& Witte, 1999; Değermenci, 2009; Demircioğlu et al., 2012; Gül, 2016; Gül et al., 2017; House, 1996; Ingram, 2003; Navarra, 2006; Tanner \& Chism, 1996; Ültay, 2012; Ültay \& Çalık, 2011; Ültay et al., 2015). The importance of this study is to examine the effects of REACT strategy on students' self-efficacy towards science learning and the effects of affective variables such as motivation, questioning learning and self-efficacy on permanence.

\section{Method}

The research was carried out with 18 students studying at 7th grade in a school in 2017-2018 education year in Kilis. The working group of study was selected by convenience sampling method. Instrumental case study method was utilized as the research method in the research (Stake, 2008). The research lasted about 14 lesson time. While the quantitative data collected through Matter Subject Context Based Success Test [MSCB-ST] developed by researchers, Questionnaire for Motivation toward Science Learning [QMSL], Self-Efficacy Scale towards Science and Technology [SESST] and Measurement of Inquiry Learning Skills Perception Devise [MILSPD], the qualitative data collected through Semi-Structured Student Opinion Form. All quantitative data 
collection tools were applied as pre-test before application, post-test after application and retention test eight weeks after the application. In the study, the quantitative data matching the normal distribution were analyzed by the dependent group's t-test, the data that did not fit the normal distribution by Wilcoxon Signed Rank Test and the qualitative data were analyzed by descriptive analysis method.

\section{Findings, Discussion and Results}

In the research, it is determined that REACT strategy has a positive effect on students' academic achievement. Student opinions obtained through semi-structured opinion form prove the accuracy of this result.

"[In the lesson] we learned more and were able to grasp the issues thoroughly” (S5).

"It was better, better to work [lesson] like this. Because we understand better" (S8).

Eight weeks later after application, it was determined that there was no statistically significant change in the achievement of the students and that the REACT strategy provided the permanence of the academic achievement of the students.

In the research, it is determined that REACT strategy has not a positive effect on students' motivation toward science learning. Although there was a $10.75 \%$ shot in favor of the post-test between the QMSL pre-test and post-test averages, this difference was not statistically significant. However, according to the results of the study, it was determined that teaching with REACT strategy provides students' persistence in science lesson.

In the research, it is determined that REACT strategy has a positive effect on students' self-efficacy towards science.The following students' opinions prove the accuracy of this result.

"My interest towards the lesson is increased. Almost I only wanted to take this class" (S3).

"I'm more confident. Because I did what I wanted to do on paper" (S6).

According to the retention test carried out eight weeks later, it was determined that REACT strategy ensure the permanence of students' self-efficacy towards science.

In the research, it is determined that REACT strategy has a positive effect on students'inquiry learning skills perception.In addition, it is concluded that teaching with REACT strategy provides students' persistent inquiring learning skills.

As a result, it is determined that REACT strategy increased the achievement of the students in the science course and ensured the permanence of the achievement; REACT strategyensured students' the permanence of motivation towards science learning; REACT strategy improved science students' self-efficacy and ensured the permanence of science self-efficacy; REACT strategyimprovedthe students'inquiry learning skills perceptionand ensured the permanence of the students'inquiry learning skills perception. However, it was concluded that the REACT strategy was not effective in improving students' motivation to learn science. 


\section{ETİK BEYANNAME}

Bu çalışmanın araştırma ve yazım sürecinde araştırmacı / araştırmacılar tarafından bilimsel ve etik kurallara uyulduğunu, farklı eserlerden yararlanılması durumunda atıfta bulunulduğunu, kullanılan verilerde herhangi bir tahrifat yapılmadığını, araştırmanın tamamının veya bir kısmının farklı bir akademik yayın platformuna yayımlanmak üzere gönderilmediǧini, belirtilen konularda araştırmanın yazarının / yazarlarının bilgi sahibi olduğunu ve gerekli kurallara uyulduğunu beyan ederim. 30/10/2020

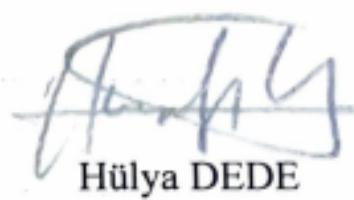

Araştırmanın Sorumlu Yazarı 